\title{
Seismic reflection data reveal the 3D structure of the newly discovered Exmouth Dyke Swarm, offshore NW Australia
}

\author{
Craig Magee $^{1}$ and Christopher Aiden-Lee Jackson ${ }^{2}$ \\ ${ }^{1}$ Institute of Geophysics and Tectonics, School of Earth Science and Environment, \\ University of Leeds, Leeds, LS2 9JT, UK \\ ${ }^{2}$ Basins Research Group (BRG), Department of Earth Science and Engineering, \\ Imperial College London, London, SW7 2BP, UK
}

Correspondence: Craig Magee (c.magee@leeds.ac.uk)

Received: 18 December 2019 - Discussion started: 13 January 2020

Revised: 19 March 2020 - Accepted: 25 March 2020 - Published: 22 April 2020

\begin{abstract}
Dyke swarms are common on Earth and other planetary bodies, comprising arrays of dykes that can extend laterally for tens to thousands of kilometres. The vast extent of such dyke swarms, and their presumed rapid emplacement, means they can significantly influence a variety of planetary processes, including continental break-up, crustal extension, resource accumulation, and volcanism. Determining the mechanisms driving dyke swarm emplacement is thus critical to a range of Earth Science disciplines. However, unravelling dyke swarm emplacement mechanics relies on constraining their 3D structure, which is difficult given we typically cannot access their subsurface geometry at a sufficiently high enough resolution. Here we use high-quality seismic reflection data to identify and examine the $3 \mathrm{D}$ geometry of the newly discovered Exmouth Dyke Swarm, and associated structures (i.e. dyke-induced normal faults and pit craters). Dykes are expressed in our seismic reflection data as 335-68 $\mathrm{m}$ wide, vertical zones of disruption (VZD), in which stratal reflections are dimmed and/or deflected from sub-horizontal. Borehole data reveal one $\sim 130 \mathrm{~m}$ wide VZD corresponds to an $\sim 18 \mathrm{~m}$ thick, mafic dyke, highlighting that the true geometry of the inferred dykes may not be fully captured by their seismic expression. The Late Jurassic dyke swarm is located on the Gascoyne Margin, offshore NW Australia, and contains numerous dykes that extend laterally for $>170 \mathrm{~km}$, potentially up to $>500 \mathrm{~km}$, with spacings typically $<10 \mathrm{~km}$. Although limitations in data quality and resolution restrict mapping of the dykes at depth, our data show that they likely have heights of at least $3.5 \mathrm{~km}$. The mapped dykes are distributed radially across a $\sim 39^{\circ}$ wide arc centred on the
\end{abstract}

Cuvier Margin; we infer that this focal area marks the source of the dyke swarm. We demonstrate that seismic reflection data provide unique opportunities to map and quantify dyke swarms in 3D. Because of this, we can now (i) recognise dyke swarms across continental margins worldwide and incorporate them into models of basin evolution and fluid flow, (ii) test previous models and hypotheses concerning the $3 \mathrm{D}$ structure of dyke swarms, (iii) reveal how dyke-induced normal faults and pit craters relate to dyking, and (iv) unravel how dyking translates into surface deformation.

\section{Introduction}

Dyke swarm emplacement can transfer large volumes of magma through the crust, over tens to thousands of kilometres, on Earth and on other planetary bodies (e.g. Fig. 1a) (Halls, 1982; Halls and Fahrig, 1987; Ernst and Baragar, 1992; Coffin and Eldholm, 1994, 2005; Wilson and Head, 2002; Bryan and Ernst, 2008; Ernst, 2014). There are three principal dyke swarm geometries: (i) parallel or linear dyke swarms, which typically develop orthogonal to a far-field $\sigma_{3}$, within and sub-parallel to rift zones (e.g. Fig. 1b) (e.g. Ebinger and Casey, 2001; Ernst et al., 2001; Paquet et al., 2007); (ii) radial dyke swarms, which form when $\sigma_{3}$ is circumferential to a large volcanic centre or mantle plume source (e.g. Fig. 1a and c) (e.g. Odé, 1957; Walker, 1986; Baragar et al., 1996; Buchan and Ernst, 2013); and (iii) circumferential dyke swarms, which likely emanate from the lateral termination of a plume head, although the stress state 
controlling their emplacement remains poorly understood (e.g. Fig. 1d) (e.g. Buchan and Ernst, 2018a, b). Component dykes within dyke swarms can be up to tens or hundreds of metres thick, and their emplacement is thought to be primarily accommodated by extending the host rock rather than through magmatic overpressure (e.g. Gudmundsson, 1983; Jolly and Sanderson, 1995; Paquet et al., 2007; Rivalta et al., 2015). Their geometry and scale means that dyke swarms can thus contribute to crustal extension, influencing plate tectonic processes on Earth and shaping other planetary bodies (e.g. Halls, 1982; Ernst and Buchan, 1997; Ebinger and Casey, 2001; Wilson and Head, 2002; Wright et al., 2006; Paquet et al., 2007; Ernst et al., 2013). Because they are typically emplaced over short time spans (5 Myr) and are sensitive to the prevailing stress field, dyke swarms also provide a record of local and/or regional syn-emplacement stress conditions and represent key spatial and temporal markers for palaeogeographic and palinspastic reconstruction (e.g. Halls, 1982; Bleeker and Ernst, 2006; Hou et al., 2010; Ju et al., 2013; Peng, 2015). Furthermore, dyke swarms may be associated with the accumulation of critical economic resources (e.g. Ernst and Jowitt, 2013; Jowitt et al., 2014) and, if they feed extensive flood basalts, may contribute to climate change and related mass extinctions (e.g. Ernst and Youbi, 2017). Unravelling the emplacement history of dyke swarms and deciphering the processes controlling their intrusion and form is therefore crucial to a wide range of pure and applied Earth Science disciplines.

Decoding dyke swarm emplacement requires knowledge of their 3D structure, which is typically inferred by quantifying and projecting downwards the plan-view morphology of dykes exposed at Earth's surface or identified in airborne or satellite imagery and remote sensing data (e.g. Halls, 1982; Halls and Fahrig, 1987; Ernst and Baragar, 1992; Coffin and Eldholm, 1994, 2005; Bryan and Ernst, 2008; Bryan et al., 2010; Hou et al., 2010; Ernst, 2014; Ernst and Youbi, 2017). Such inferences of 3D structure may be augmented by direct mapping of the local subsurface structure of dyke swarms, or component dykes, intersected in mines or imaged in geophysical data (e.g. Wall et al., 2010; Kavanagh and Sparks, 2011; Keir et al., 2011). Integrating these datasets typically emphasises the lateral variability in dyke swarm architecture, although they can show how dyke properties change over vertical distances of hundreds of metres (e.g. Kavanagh and Sparks, 2011). In contrast, seismic reflection data can be used to track changes in dyke swarm structure with depths over hundreds to thousands of metres (Phillips et al., 2018). For example, Phillips et al. (2018) demonstrated that the width of a dyke swarm imaged offshore southern Norway increased with depth, implying that the plan-view morphology of a dyke swarm may not be a proxy for its 3D geometry (or total volume); i.e. the plan-view morphology of a dyke swarm is a function of its attitude relative to the present topography. We can use different physical, analytical, and numerical modelling approaches to evaluate the $3 \mathrm{D}$ geometry of dyke swarms and to establish how their structure can be inferred from principally 2D surface-based analyses. However, model predictions are difficult to validate without constraints on the true 3D form of natural dyke swarms (e.g. Macdonald et al., 1988; Jolly and Sanderson, 1995; Paquet et al., 2007; Bunger et al., 2013). Advancing our understanding of dyke swarm emplacement thus requires a method for imaging their 3D structure in detail (e.g. Magee et al., 2018, 2019; Phillips et al., 2018).

Reflection seismology has proved to be a powerful tool for imaging the 3D structure of magma plumbing systems (see Magee et al., 2018, and references therein). Yet vertical dykes are commonly expressed as very subtle reflection discontinuities within seismic reflection data, and they are thus easily and often overlooked (e.g. Fig. 2) (e.g. Jaunich, 1983; Kirton and Donato, 1985; Wall et al., 2010; Bosworth et al., 2015; Ardakani et al., 2017; Holford et al., 2017; Malehmir et al., 2018; Plazibat et al., 2019). Whilst dykes have been recognised in seismic reflection data (e.g. Fig. 2), we are not aware of any concerted effort to quantify their 3D geometry across large areas (tens of kilometres) using this technique. Here, we use an extensive suite of $2 \mathrm{D}$ and $3 \mathrm{D}$ seismic reflection data from the North Carnarvon Basin, offshore NW Australia, to examine the 3D structure of a previously unidentified dyke swarm, which we name the Exmouth Dyke Swarm. We aim to (i) characterise the dyke swarm's seismic expression and identify diagnostic criteria that can be used to identify dykes in other seismic reflection datasets, (ii) quantify dyke geometry (e.g. horizontal length and spacing) and test predictions of how dyke populations develop in time and space, and (iii) decipher the tectono-magmatic and geodynamic setting of the Exmouth Dyke Swarm.

\section{Geological setting}

The North Carnarvon Basin is located on the $\sim 500 \mathrm{~km}$ wide magma-rich Gascoyne Margin, offshore NW Australia (Fig. 3a). The basin extends southward onto the $~$ $100-150 \mathrm{~km}$ wide Cuvier Margin, which is separated from the Gascoyne Margin by the Cape Range Fracture Zone (Fig. 3a). Tectonic elements within the North Carnarvon Basin include the Exmouth Plateau; the Exmouth, Barrow, and Dampier sub-basins; and the Carnarvon Terrace (Fig. 3a). Basin formation involved several episodic rifting events between the Late Carboniferous and Early Cretaceous, with sub-basin development initiating in the Late Triassic (Fig. 3b) (e.g. Willcox and Exon, 1976; Stagg and Colwell, 1994; Tindale et al., 1998; Longley et al., 2002; Jitmahantakul and McClay, 2013; Gartrell et al., 2016; Black et al., 2017). This Late Triassic rifting continued until the near end Callovian $(\sim 164 \mathrm{Ma})$, when extension was interrupted by a phase of regional uplift recorded in the formation of a major unconformity (Fig. 3b) (e.g. Tindale et al., 1998; Jitmahantakul and McClay, 2013; Gartrell et al., 2016). Renewed ex- 

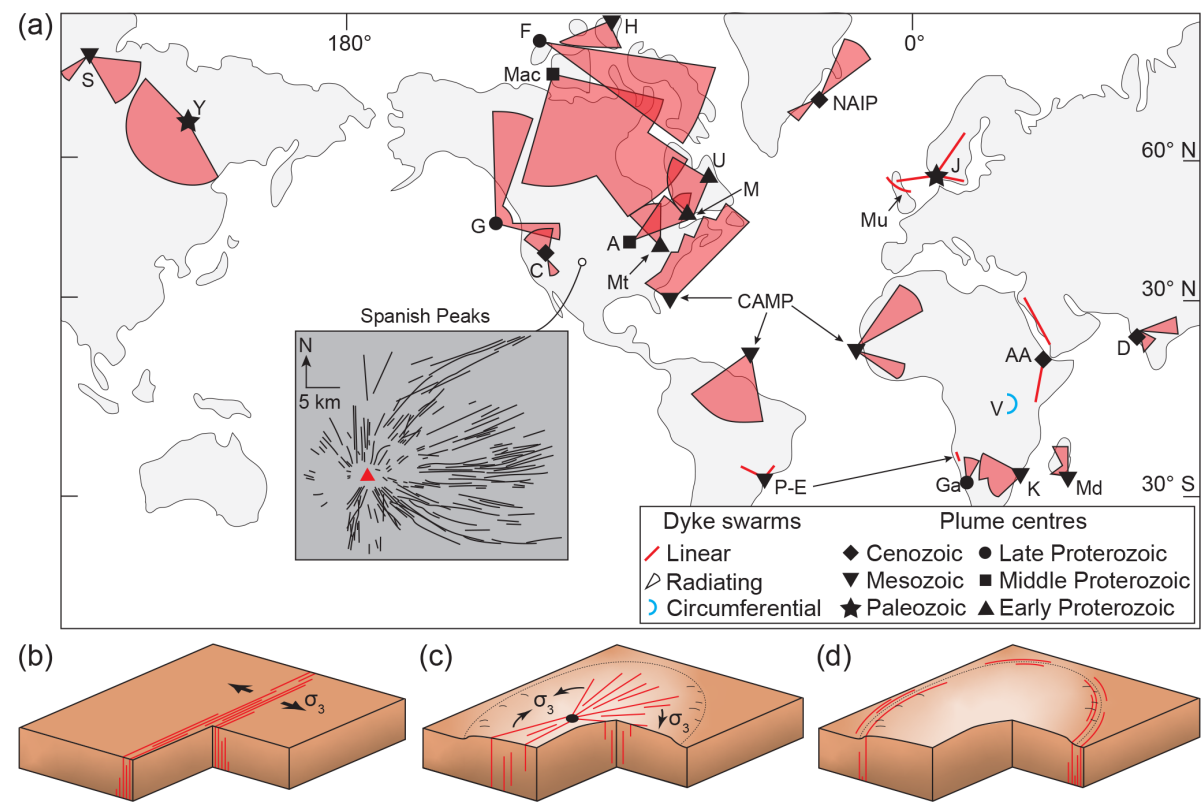

Figure 1. (a) Map of the major dyke swarms on Earth, highlighting their form and age of associated mantle plume sources if relevant (modified from Ernst, 2014; Magee et al., 2019). Dyke swarms shown include A =1140 Ma Abitibi swarm, precursor to the 1115-1085 Ma Keweenawan LIP; AA = 30-0 Ma Afar-Arabian swarms; C=17-0 Ma Columbia River swarms; CAMP=201 Ma Central Atlantic Magmatic Province swarm; D =66 Ma Deccan swarm; F = Franklin swarm; G=779 Ma Gunbarrel swarms; Ga=799 Ma Gannakouriep swarm; H = 130-90 Ma High Arctic LIP (HALIP) swarm; J = 301 Ma Skagerrak (Jutland) swarms; K = 183 Ma Karoo swarms; M = 2510 Ma Mistassini swarm; Mac = 1267 Ma Mackenzie swarm; Md=89 Ma Madagascar swarm; Mt=2480-2450 Ma Matachewan swarm; NAIP =6255 Ma North Atlantic Igneous Province swarms (e.g. Mu is the Mull dyke swarm); P-E = 135-128 Ma Paraná-Etendeka dyke swarms; $\mathrm{S}=251$ Ma Siberian Traps swarm; U =2217-2210 Ma Ungava swarm; Y=370 Ma Yakutsk-Vilyui swarm. Inset: map of the radial dyke swarm around the Spanish Peaks volcanic centre (redrawn from Odé, 1957). (b-d) Schematic diagrams depicting parallel/linear (b), radiating (c), and circumferential (d) dyke swarms.

tension in the Late Jurassic to Early Cretaceous, which likely initiated in the Tithonian and occurred in response to rifting between Greater India and Australia (Fig. 3b) (e.g. Tindale et al., 1998; Longley et al., 2002; Stagg et al., 2004; Magee et al., 2016a). Rifting during the Early Cretaceous involved discrete periods of unconformity development and culminated in continental break-up at $\sim 130$ Ma during the Hauterivian (Fig. 3a and b) (e.g. Willcox and Exon, 1976; Stagg et al., 2004; Heine and Müller, 2005; Robb et al., 2005; Direen et al., 2008). Following continental break-up, post-rift thermal subsidence has controlled passive margin evolution (e.g. Tindale et al., 1998; Kaiko and Tait, 2001; Jitmahantakul and McClay, 2013). During the post-rift period, several tiers of polygonal fault systems developed across much of the North Carnarvon Basin (e.g. Velayatham et al., 2019).

\subsection{Stratigraphic framework}

Sedimentary sequences within the North Carnarvon Basin are typically $10-18 \mathrm{~km}$ thick, and locally up to $24 \mathrm{~km}$ thick in the sub-basins, making it difficult to seismically image the $<10 \mathrm{~km}$ thick crystalline basement (e.g. Fig. 3c) (e.g. Mutter and Larson, 1989; Stagg and Colwell, 1994; Tindale et al., 1998; Stagg et al., 2004; Reeve et al., 2016). Borehole data show the dyke-hosting interval of interest comprises (Fig. 3b and c) (i) siliciclastic rocks of the Late Permian-toLate Triassic marine Locker Shale and fluvio-deltaic Mungaroo Formation, which are up to $9 \mathrm{~km}$ thick (e.g. Hocking et al., 1987; Tindale et al., 1998; Longley et al., 2002; Stagg et al., 2004); (ii) Late Triassic-to-Late Jurassic marine claystones and marls (i.e. the Brigadier and North Rankin formations, Murat Siltstone, Athol Formation, and Dingo Claystone), which are up to $4 \mathrm{~km}$ thick in the Barrow and Exmouth sub-basins but only preserved as a condensed $<100 \mathrm{~m}$ thick succession on the Exmouth Plateau (e.g. Hocking, 1992; Stagg and Colwell, 1994; Tindale et al., 1998; Stagg et al., 2004; Jitmahantakul and McClay, 2013); and (iii) Late Jurassic-to-Early Cretaceous (Tithonian-to-Valanginian; 146.7-138.2 Ma) clastic deltaic rocks of the Barrow Group and the overlying coastal Birdrong Sandstone (e.g. Reeve et al., 2016; Paumard et al., 2018). Late Jurassic-to-Early Cretaceous rift-related unconformities have, in places, eroded down into the Mungaroo Formation (Fig. 3c) (e.g. Reeve et al., 2016). 

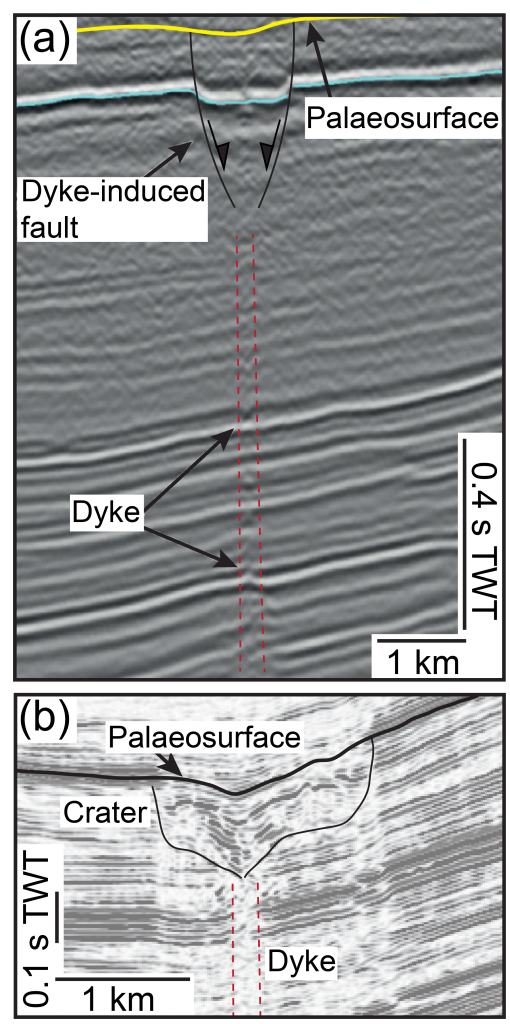

Figure 2. (a) Dyke and overlying graben-bounding faults recognised in seismic reflection data from Egypt (modified from Bosworth et al., 2015). Note the dyke corresponds to minor deflections in background stratigraphic reflections. (b) Vertical zone of disturbance within seismic reflection data from the North Sea, where the amplitude of background stratigraphic reflections is relatively diminished and deflected upwards, inferred to be a dyke (Wall et al., 2010). A crater that truncates underlying strata and contains high-amplitude continuous-to-chaotic reflections is developed above the dyke (Wall et al., 2010).

\subsection{Mesozoic tectonic faulting}

Mesozoic extension produced two principal fault arrays in the North Carnarvon Basin. Late Triassic-to-Middle Jurassic rifting led to development of NE-SW-striking dominostyle normal faults that have $>1 \mathrm{~km}$ of throw (e.g. Fig. 3c) (e.g. Tindale et al., 1998; Jitmahantakul and McClay, 2013; Magee et al., 2016a; Black et al., 2017). Late Jurassic-toEarly Cretaceous rifting was characterised by the formation of broadly NE-SW-striking low-throw $(<0.1 \mathrm{~km})$ normal faults that are primarily strata-bound between the Callovian and near Base Cretaceous or Valanginian unconformities (e.g. Tindale et al., 1998; Jitmahantakul and McClay, 2013; Magee et al., 2016a; Black et al., 2017). During the main period of Late Jurassic-to-Early Cretaceous rifting, as well as during younger faulting events (e.g. polygonal faulting), Late Triassic-to-Middle Jurassic normal faults were locally reactivated (e.g. Jitmahantakul and McClay, 2013;
Magee et al., 2016a). Stretching factors of $\beta<1.2$ for both Mesozoic rift events indicate the Exmouth Plateau accommodated only minor upper crustal extension during these periods (e.g. Driscoll and Karner, 1998; Bilal et al., 2018).

\subsection{Magmatism}

Igneous activity throughout the Late Jurassic-to-Early Cretaceous resulted in (Fig. 3b) (i) sill-complex emplacement, which likely began in the Kimmeridgian prior to onset of rifting, across the Exmouth Plateau, Exmouth Sub-basin, and Carnarvon Terrace (e.g. Fig. 3a) (e.g. Symonds et al., 1998; Holford et al., 2013; Magee et al., 2013a, b, 2017); (ii) intrusion of dykes, perhaps genetically related to sill intrusion (Rohrman, 2015); and (iii) development of a magmarich continent-ocean transition zone (COTZ) spanning the north-western edges of the Gascoyne and Cuvier margins in the Valanginian to Hauterivian ( 136-130 Ma; Fig. 3a) (e.g. Mihut and Müller, 1998; Symonds et al., 1998; Direen et al., 2007; Rey et al., 2008; Reeve et al., 2019). High-amplitude seismic reflections observed towards the base of the crust (Fig. 3c), coupled with a coincident downward increase in seismic velocity (from 6.2 to $\sim 7.4 \mathrm{~km} \mathrm{~s}^{-1}$ ), suggest igneous material was also emplaced in or below the lower crust during the Late-Jurassic to Early Cretaceous ( 165-136 Ma) (Mutter and Larson, 1989; Frey et al., 1998; Stagg et al., 2004; Rohrman, 2013). Previous studies have attributed this Late Jurassic-to-Early Cretaceous magmatism to rift-related decompression melting (e.g. Karner and Driscoll, 1999), perhaps enhanced by small-scale mantle convection (e.g. Mutter et al., 1988; Hopper et al., 1992; Mihut and Müller, 1998), and/or mantle plume activity (e.g. Müller et al., 2002; Rohrman, 2013, 2015; Black et al., 2017).

\section{Dataset and methods}

Dykes are rarely imaged in seismic reflection data because their sub-vertical orientation preferentially reflects seismic energy deeper into the subsurface rather than returning it to the surface to be recorded (e.g. Thomson, 2007; Eide et al., 2018). Dykes identified in the field and/or in aeromagnetic data have been indirectly recognised in co-located seismic reflection data where a localised reduction in returned seismic energy disrupts the continuity and strength (amplitude) of reflections associated with stratigraphic layering (e.g. Fig. 2) (e.g. Kirton and Donato, 1985; Wall et al., 2010; Bosworth et al., 2015; Ardakani et al., 2017); i.e. in these cases, dykes do not correspond to discrete reflections but instead appear as "vertical zones of disruption" (VZDs). Whilst dykes can thus be recognised in seismic reflection data, vertical strikeslip and normal faults, and non-magmatic fluid flow conduits (e.g. gas chimneys), may also be expressed as VZDs. To avoid interpretational bias, we describe the features of interest in this study as VZDs, and we collect additional data 

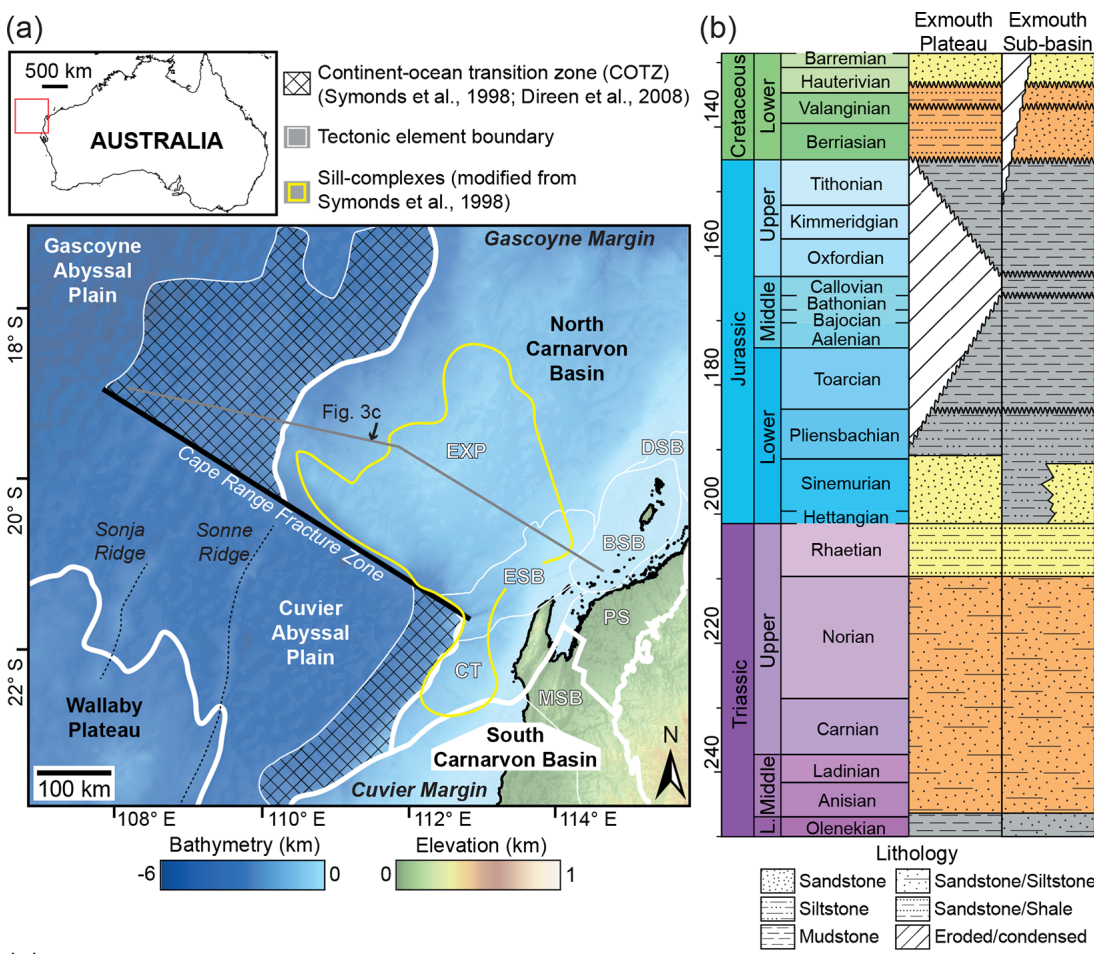

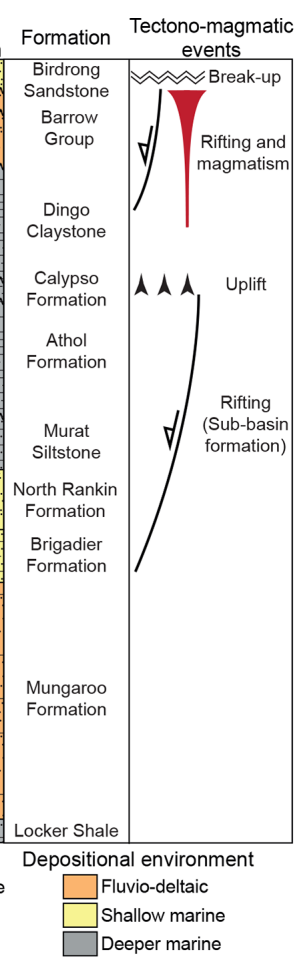

(c)

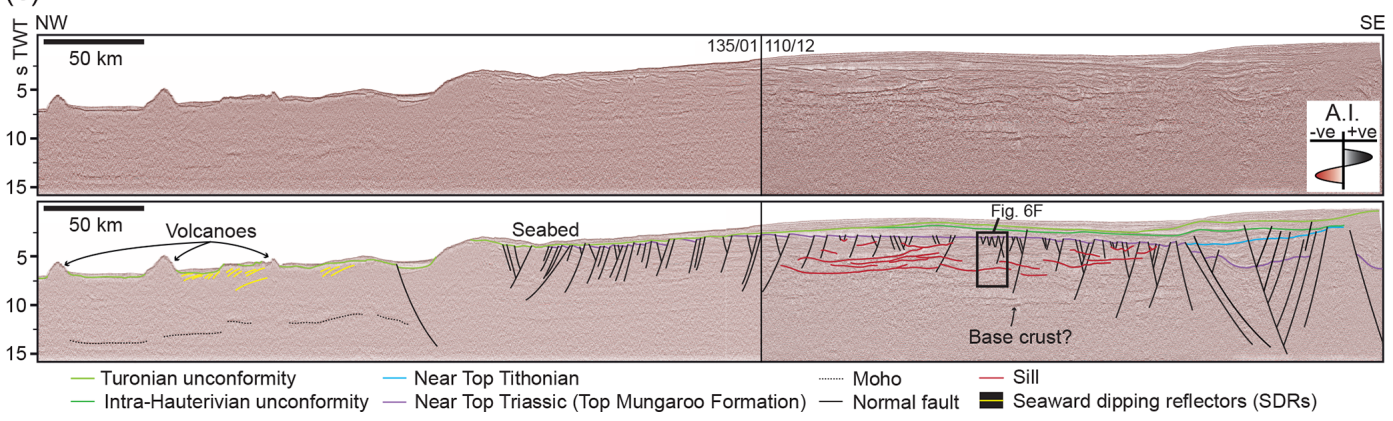

Figure 3. (a) Location map of the southern portion of the North Carnarvon Basin, which spans the Gascoyne Margin and extends onto the Cuvier Margin. Key tectonic elements include EXP = Exmouth Plateau; DSB = Dampier Sub-basin; BSB = Barrow Sub-basin; ESB = Exmouth Sub-basin; CT = Carnarvon Terrace; MSB = Merlinleigh Sub-basin; and the PS = Peedamullah Shelf. The map also shows the approximate boundary of sill complexes in the North Carnarvon Basin (modified from Symonds et al., 1998; Holford et al., 2013). (b) Tectono-stratigraphic column for the Exmouth Plateau and Exmouth Sub-basin, which also highlights the relative duration and abundance of Late Jurassic-to-Early Cretaceous magmatism (based on Symonds et al., 1998; Tindale et al., 1998; Longley et al., 2002; Reeve et al., 2016). Undulating lines mark unconformities. (c) Uninterpreted and interpreted seismic section, combining lines AGSO 135/01 and AGSO 110/12, showing the crustal structure of the study area (see Fig. 3a for location). Reflection polarity here, and elsewhere, is defined by a schematic seismic wavelet showing acoustic impedance (A.I.). See Supplement Fig. S1 for an enlarged version.

and make further observations to inform a critical discussion of their likely origin.

We use $83 \mathrm{D}$ and $632 \mathrm{D}$, time-migrated seismic surveys to map 26 VZDs across $\sim 40000 \mathrm{~km}^{2}$ of the North Carnarvon Basin (Fig. 4a and b); the properties of each seismic survey are provided in the Supplement Table S1. Visual inspection of the data and extraction of variance volume attributes, which highlight trace-to-trace variations in seismic wavelets to reveal structural (e.g. faults and VZDs) and stratigraphic (e.g. channel edges) discontinuities (Brown, 2011), allow us to identify VZDs in the 3D seismic volumes. These VZDs were mapped on sections oriented orthogonal to their strike every $\sim 250-1200 \mathrm{~m}$. In places, the VZDs were obscured by tectonic faults and could not be mapped at regular intervals. Along-strike projection of mapped VZDs outside of the 3D seismic volumes guided their interpretation on 2D seismic lines, where poorer data quality and/or lower resolution hindered their recognition. We were able to confidently recognise VZDs in nine 2D seismic surveys (e.g. Fig. 4c and d), although we cannot rule out their presence in other datasets. 
(a)

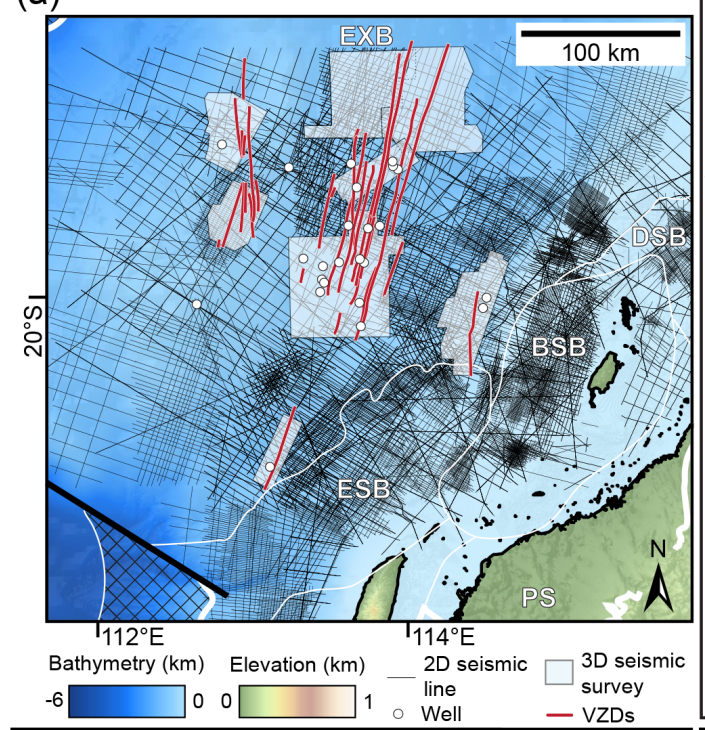

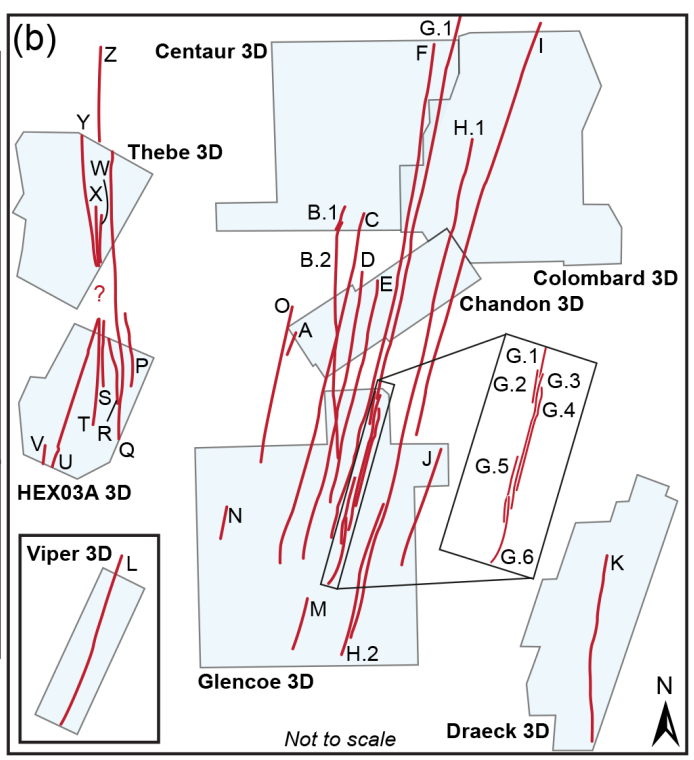

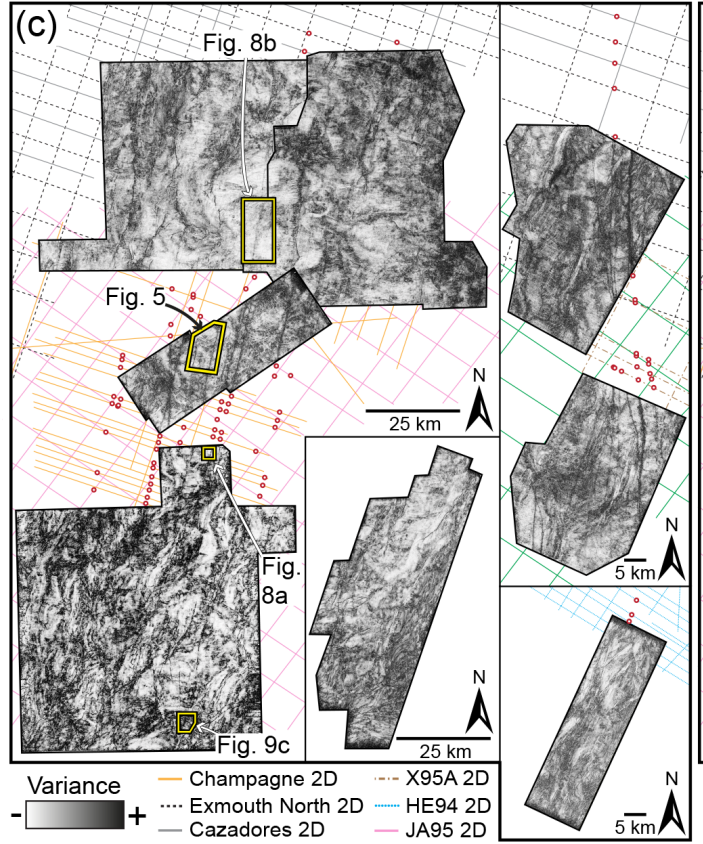

(d)

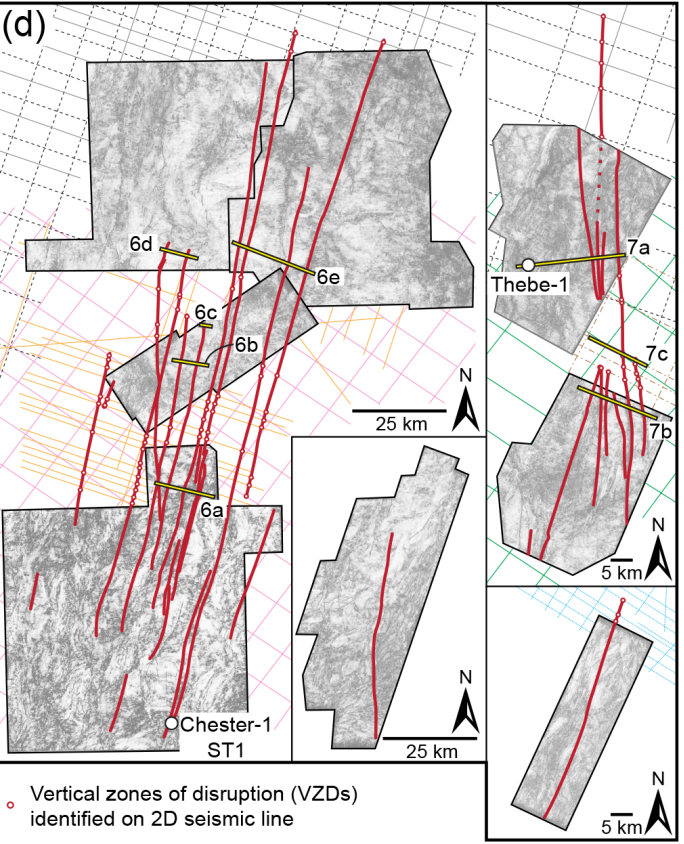

Figure 4. (a) Location map showing the 2D and 3D seismic surveys and 24 wells used in the study, as well as the plan-view configuration of the 26 vertical zones of disturbance (VZDs). See Fig. S2 for a map showing well names. (b) Zoomed-in schematic view of the mapped VZDs and the eight 3D seismic reflection surveys used. (c-d) Uninterpreted and interpreted variance time slices showing that the VZDs correspond to subtle, long, linear features; time slices shown are at $4.5 \mathrm{~s}$ TWT (two-way travel time) for the Chandon, Glencoe, Centaur, Colombard, Draeck, and Viper 3D surveys but at $3.5 \mathrm{~s}$ TWT for the Thebe and HEX03A surveys. The nine 2D seismic reflection surveys containing observed VZDs and used to tie VZD traces between 3D surveys are also shown. Yellow bars in (d) highlight section locations shown in Figs. 6 and 7.

In addition to mapping VZDs, we used biostratigraphic and well-log data from 24 wells to identify and interpret two key stratigraphic horizons across the study area: (i) the $\sim 148 \mathrm{Myr}$ near Base Cretaceous unconformity (BC) and (ii) the near Top Mungaroo Formation (TM), which is broadly equivalent to the Norian-Rhaetian boundary (i.e. intra-Upper Triassic) (Figs. 4a, the Supplement Fig. S2).
Where we observed fluvial channels within the Triassic strata using variance time slices (e.g. Fig. 5), we locally mapped intra-Mungaroo horizons to assess channel continuity across identified VZDs; this helped us assess VZD kinematics. We also interpreted key structures associated with the VZDs, including overlying normal fault systems, pipes, and subcircular depressions. 


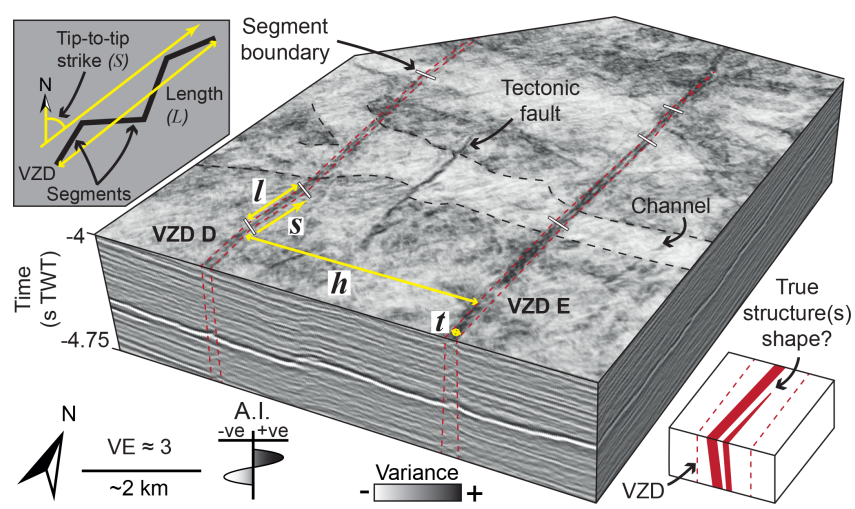

Figure 5. Interpreted 3D view of vertically exaggerated (VE) seismic reflection data, which images parts of VZDs D and E and highlights recorded measurements: $t=\mathrm{VZD}$ thickness; $h=\mathrm{VZD}$ spacing; $s=$ VZD segment strike; $l=$ VZD segment length (see Fig. S3 for uninterpreted version). Note the channel on the plan-view variance time slice is not laterally offset where it is cross-cut by the VZDs. Depth shown in seconds two-way travel time (s TWT). See Fig. 4c for location. Inset top-left: plan-view sketch depicting the tip-to-tip length $(L)$ and strike $(S)$ measurements for an entire VZD. Inset bottom-right: schematic diagram showing how a VZD's geometry may not correspond to the true shape of the structure, or structures, it represents.

\subsection{Quantitative analysis}

The mechanics and dynamics of dyke swarm emplacement controls the geometry of its component dykes (e.g. Gudmundsson, 1987; Jolly and Sanderson, 1995; Mège and Korme, 2004; Bunger et al., 2013). For example, horizontal dyke lengths within a swarm are expected to display a powerlaw distribution and may be used to differentiate feeder and non-feeder dykes within a given population (Mège and Korme, 2004). Within any given population, the statistical range of dyke thicknesses and spacings can also provide insights into the strength of host rock and/or magma source conditions (Bunger et al., 2013; Krumbholz et al., 2014). These predicted distributions for dyke properties within a swarm also allow us to test whether an observed dyke set comprises one or multiple generations of intrusion, perhaps originating from different sources (e.g. Krumbholz et al., 2014). We quantify VZD structure and compare our results to predicted distributions to help unravel the mechanics and dynamics of VZD formation.

We measured the plan-view tip-to-tip horizontal length $(L)$ and strike $(S)$ of each VZD (Fig. 5). Many VZDs display minor but abrupt changes in strike along their length (e.g. Fig. 5). These minor changes in strike subdivide the VZDs into discrete planar segments, for which we measured strike $(s)$ and horizontal length $(l)$ (Fig. 5). Where coverage of 3D seismic volumes was sufficient, we also measured VZD thickness $(t)$ and spacing ( $h$; the horizontal distance between two dykes) orthogonal to strike on variance time slices at
$4.5 \mathrm{~s}$ two-way time (TWT) (Fig. 5); we specifically measured $t$ and $h$, as well as the depth to VZD tips, along $35 \sim \mathrm{E}-\mathrm{W}$ trending, $\sim 51 \mathrm{~km}$ long transects spaced $\sim 4.7 \mathrm{~km}$ apart. Because data quality generally decreases with depth within individual seismic surveys, defining the base of individual VZDs is problematic, making it difficult to ascertain whether most VZDs truly terminate downwards or if they extend below the 2D or 3D survey limits. We therefore only qualitatively assess VZD vertical height $(H)$.

\subsection{Seismic resolution}

We used time-depth plots derived from the check-shot data available for the 24 wells to estimate seismic velocities (Fig. S4 and Table S2). Because the VZDs extend below the total depth of all wells, we estimated seismic velocities $(v)$ through the interval of interest by extrapolating a second-order polynomial trend line through the cumulative check-shot data (Fig. S4). The dominant frequency $(f)$ of the 2D and 3D seismic surveys broadly decrease with depth from a maximum of $\sim 30-40 \mathrm{~Hz}$ at the top of the interval of interest $(\sim 2.8-2.9 \mathrm{~s}$ TWT; $\sim 2.5-2.7 \mathrm{~km})$ to a minimum of $\sim 5-20 \mathrm{~Hz}$ at $\sim 5.9-6.0 \mathrm{~s}$ TWT $(\sim 9.7-10.1 \mathrm{~km})$. We calculated the average interval velocities for $\sim 2.8-2.9 \mathrm{~s}$ TWT $\left(\sim 3.0 \mathrm{~km} \mathrm{~s}^{-1}\right)$ and $\sim 5.9-6.0 \mathrm{~s}$ TWT $\left(\sim 6.4 \mathrm{~km} \mathrm{~s}^{-1}\right)$. Coupled with the dominant frequency data, these average interval velocities allowed us to estimate the dominant wavelength $(\lambda=v / f)$ of the data and constrain the limits of separability $(\sim \lambda / 4)$ and visibility $(\sim \lambda / 30)$ (Brown, 2011). The limit of separability corresponds to the minimum vertical distance between two interfaces required for them to produce distinct seismic reflections within a survey (Brown, 2011). If the vertical distance between two interfaces is between the limits of separability and visibility, their reflections will interfere and cannot be deconvolved; i.e. they produce tuned reflection packages (Brown, 2011). Interfaces separated by vertical distances less than the limit of visibility will be indistinguishable from noise (Brown, 2011). Our calculations indicate that the limits of separability and visibility at the top of the interval of interest, within the Early Cretaceous Barrow Group, are $\sim 19-25$ and $\sim 2-3 \mathrm{~m}$, respectively. Towards the base of the 3D seismic surveys at $\sim 5.9-6.0$ s TWT, the limits of separability and visibility decrease to $\sim 80-320$ and $\sim 11-43 \mathrm{~m}$, respectively.

\subsection{Errors}

Here we carefully consider the errors associated with our quantitative analysis of VZD geometry. For example, synthetic seismic forward modelling indicates dyke-related VZD thickness is dependent on data quality and resolution, and thus it likely does not equal dyke thickness (Eide et al., 2018). Data quality and resolution, in turn, are influenced by a range of geophysical (e.g. acquisition and processing parameters) and geological (e.g. faults may locally inhibit 
imaging) factors. The different acquisition and processing histories of the seismic surveys we use, coupled with spatial variations in the geology of the study area, therefore makes it challenging to assess the likely errors associated with our measurements of VZD geometry; e.g. we cannot easily determine how closely the mapped and measured VZD geometry reflects the thickness and spacing of the structures they correspond to (e.g. Fig. 5). The local strike and dip of VZDs may also potentially differ from that of their corresponding structure(s) (e.g. Fig. 5), although we consider these variations to be negligible given their high length-tothickness and height-to-thickness aspect ratios. Because we do not know how seismic velocity varies laterally away from areas of borehole control, we do not depth-convert the seismic reflection data, instead presenting measurements in time (milliseconds TWT) rather than depth (in metres). Overall, the described data quality, resolution, and depth conversion error sources do not compromise the precision of VZD thickness, length, and height measurements. Rather, uncertainties and/or variation in these error sources are introduced when attempting to relate VZD geometry to that of the geological features they represent, which we consider in the Discussion section. However, to account for potential errors introduced by human imprecision during measurement, we conservatively consider, based on personal experience, that each quantitative parameter could have an arbitrary error of either (i) $\pm 0.05 \mathrm{~s}$ TWT if the property analysed is measured in time (e.g. VZD upper tip depth) or (ii) $\pm 50 \mathrm{~m}$ if distances (e.g. VZD length, thickness, and spacing) are measured in plan view. These values are based on personal experience. To help geoscientists more used to working with geological (e.g. field) rather than geophysical data, and to provide an overall sense of scale, we use velocity data to provide approximate depth-converted values (in metres) for each measurement in time. Due to uncertainty in the velocities used for these depth conversions, we cannot ascertain their accuracy and thus present them with arbitrary errors of $\pm 10 \%$.

\section{Results}

\subsection{Vertical zones of disruption (VZD)}

\subsubsection{Seismic expression}

We mapped 26 (A-Z) major VZDs, three of which comprise closely overlapping but apparently physically unconnected sections (i.e. VZDs B.1-B.2, G.1-G.6, and H.1-H.2; Fig. 4). The VZDs are broadly planar and dip at $\geq 80^{\circ}$ (e.g. Figs. 57). Where data quality is high, sub-horizontal stratigraphic reflections within the VZDs are deflected upwards, displaying chevron-like geometries, and typically have lower amplitudes relative to their regional attitude (e.g. Fig. 6a and b). In places, the VZDs cross-cut igneous sill-related reflections, which are similarly deflected upwards (e.g. Fig. 6b). Where data quality is lower, the VZDs are subtle and typically only marked by a reduction in amplitude and/or minor geometrical distortion of the stratigraphic reflections they cross-cut (e.g. Figs. 6d-f and 7). On some 2D and 3D seismic sections, particularly where data quality is poor and tectonic faults inhibit imaging, we could not recognise VZDs in locations where we predicted them to occur based on their along-strike projection (e.g. Fig. 7c). Conversely, we identified some additional VZDs on individual 2D seismic lines but could not map these on neighbouring sections located as little as $5 \mathrm{~km}$ along-strike (e.g. Fig. 6f); in these cases it was difficult to determine if the VZDs truly terminated along-strike or whether they were simply not imaged on adjacent lines. Where VZDs cross-cut pre-existing fluvial channels or linear structures within the Mungaroo Formation, there is no resolved vertical or lateral offset of these potential host rock strain markers (e.g. Figs. 5 and 8).

\subsubsection{Borehole expression}

The deviated Chester-1 ST1 well intersects VZD H.1 at a depth of $\sim 4.7-5.0 \mathrm{~km}$ (Fig. 9a-c) (Childs et al., 2013). Where they intersect, the borehole has an inclination of $18^{\circ}$ (from vertical), whereas VZD H.1 is $\sim 130 \pm 50 \mathrm{~m}$ wide, strikes $\sim 003^{\circ}$, and dips at $80^{\circ} \mathrm{W}$ (Fig. 9a-c). Cuttings and well-log data reveal the sampled section of VZD H.1 comprises a siliciclastic sedimentary sequence that contains a $48 \mathrm{~m}$ thick interval of altered basalt between 4.911 and $4.959 \mathrm{~km}$ (Fig. 9d) (Childs et al., 2013). Compared to the encasing siliciclastic rock, the altered basalt has a low gamma ray (down to $\sim 6$ API (American Petroleum Institute)) and neutron porosity (down to $\sim 7 \mathrm{pu}$ (porosity units)) signature, but relatively high density (up to $\sim 2.9 \mathrm{~g} \mathrm{~cm}^{3}$ ), resistivity $(\sim 6200 \mathrm{ohm} \mathrm{m})$, and acoustic slowness $\left(\sim>90 \mathrm{~ms} \mathrm{ft}^{-1}\right)$ values (Fig. 9d) (Childs et al., 2013). An intra-Mungaroo seismic reflection coincident with the identified basalt has a negative polarity and locally displays a moderate amplitude (Fig. 9a-c). Where VZDs H.1 and H.2 cross-cut the intra-Mungaroo reflection, its amplitude is locally reduced (Fig. 9c).

\subsubsection{Geometry}

In plan view, the VZDs are linear, ranging in horizontal length $(L)$ from $\sim 4-171 \mathrm{~km}$ and with tip-to-tip strikes $(S)$ between 353 and $021^{\circ}$ (Figs. 4 and 10a; Table 1). Overall, the VZDs have a mean $S$ of $008^{\circ}$ and broadly display a westwards progression from $\sim$ NNE-SSW striking to $\sim$ NNWSEE striking (Figs. 4 and 10a). Only the $\sim \mathrm{N}$-S-striking $\left(002^{\circ}\right)$ VZD B intersects other VZD traces (i.e. VZDs C and D; Fig. 4); the resolution of the data is insufficient to determine whether the VZDs merge at these intersections or if one cross-cuts and potentially offsets the other. Depending on their form between the Thebe and HEX03A datasets, where tectonic faulting inhibits their imaging on the intervening 

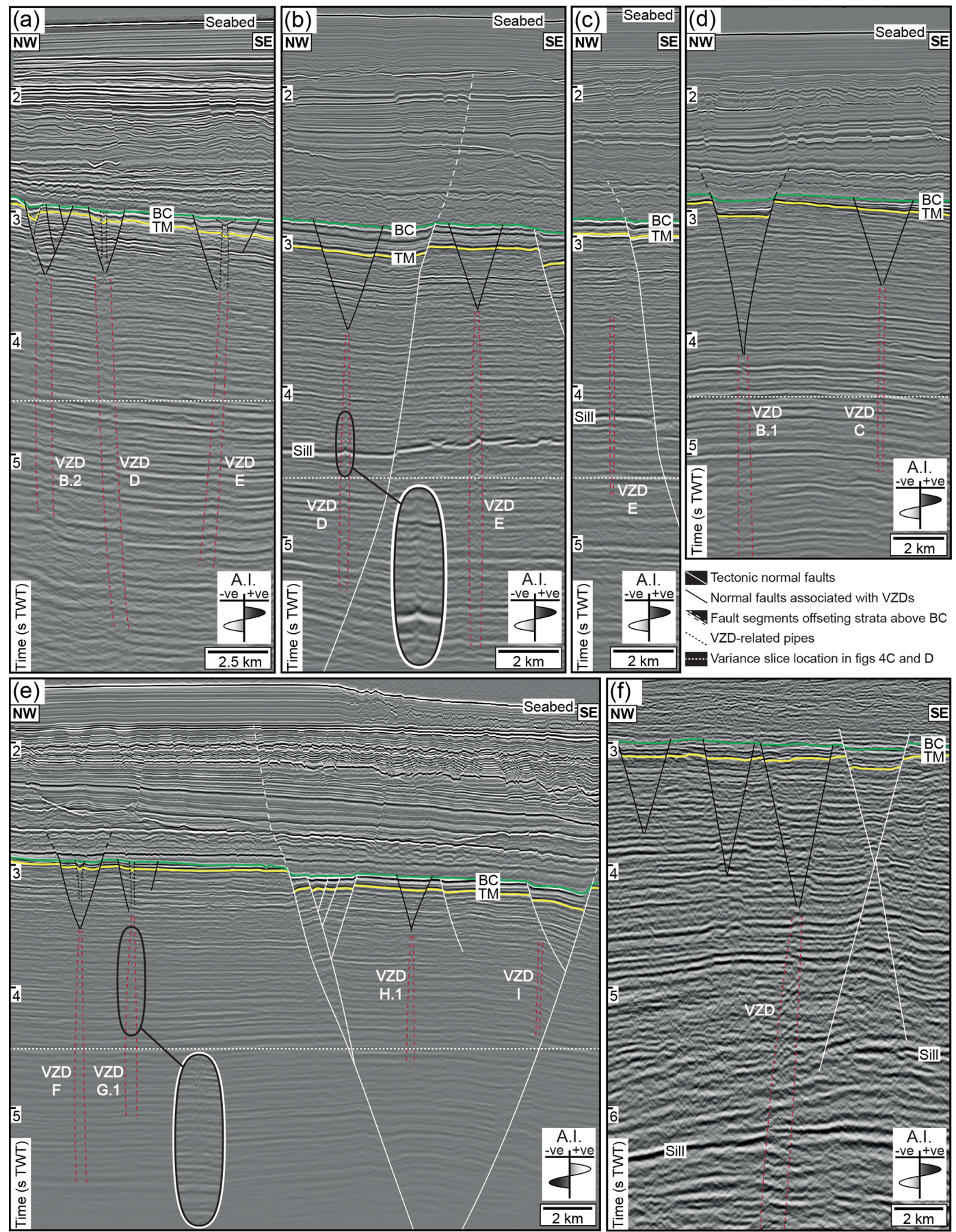

Figure 6. (a-f) Interpreted seismic sections from different surveys demonstrating the variations in VZD expression. The near Top Mungaroo horizon (TM) and near Base Cretaceous unconformity (BC) are shown. Normal fault-bounding grabens, which occasionally contain pipe-like features, occur directly above and converge on VZD upper tips; these VZD-related faults are shorter and accommodate less throw relative to larger tectonic faults. For clarity, fault displacement arrows are omitted. See Fig. 4d for line locations. See Fig. S5 for uninterpreted version.

2D seismic lines, VZDs S-Y may also intersect or connect (Figs. 4 and 7). Along most (94\%) of the mapped VZDs, minor but abrupt changes in strike allow us to sub-divide them into numerous connected segments (Figs. 4, 5, and 10b). Across the mapped VZDs, we recognise 280 discrete seg- ments (e.g. Dyke H.1 comprises 26 segments), which have strikes $(s)$ between $350^{\circ}$ and $044^{\circ}$, and horizontal lengths $(l)$ of $0.4 \pm 0.05$ to $33.1 \pm 0.05 \mathrm{~km}$ (Figs. 4 and 10b; Table S3). Both $L$ and $l$ display a relatively good fit with log-normal 


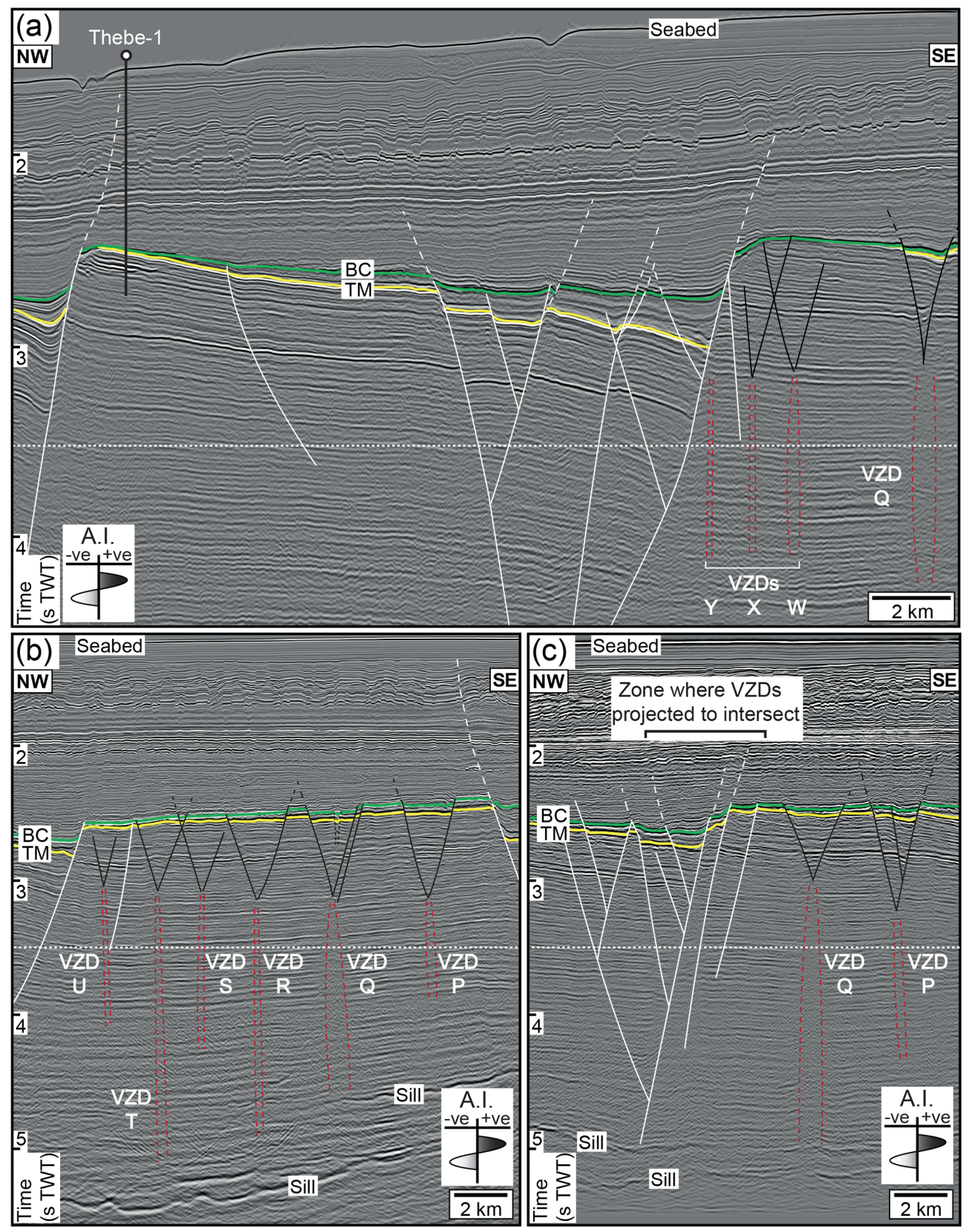

Figure 7. (a-c) Interpreted seismic sections from different surveys demonstrating the variations in VZD expression. See Fig. 4d for line locations and Fig. 6 for key. See Fig. S6 for uninterpreted version.

and negative exponential distributions and poorer fits to normal and power-law distributions (Fig. 10c).

The depth of VZD upper tips can be mapped relatively accurately within 3D seismic surveys, although convergence of overlying graben-bounding normal faults can locally inhibit their imaging (e.g. Figs. 6 and 7). Within the Glencoe, Chandon, Centaur, and Colombard 3D surveys, the upper tips of VZDs occur between $3.4 \pm 0.05 \mathrm{~s}$ TWT and $\sim 4.5 \pm 0.05 \mathrm{~s}$ TWT ( $~ 3.5 \pm 0.35-5.8 \pm 0.58 \mathrm{~km})$ (Fig. 6a-e and 11a; Table S4); the upper tip depths of these VZDs have a com- bined geometric mean of $3.7 \pm 0.05 \mathrm{~s}$ TWT $(\sim 4.1 \pm 0.41 \mathrm{~km})$ and a standard deviation of $0.2 \mathrm{~s}$ TWT. The upper tips of VZDs imaged within the Thebe and HEX03A 3D seismic surveys, which lie in the western part of the study area, occur at $\sim 3 \pm 0.1 \mathrm{~s}$ TWT $(\sim 2.9 \pm 0.29 \mathrm{~km})$ (e.g. Fig. 7). Regardless of their precise depth, VZD upper tips across the study area are consistently located $1 \mathrm{~s}$ TWT beneath the near Base Cretaceous unconformity (e.g. Figs. 6 and 7). The expression of all VZDs, at some point along their length, continues below $\sim 5 \mathrm{~s}$ TWT $(\sim 7 \pm 0.7 \mathrm{~km})$, where they either 

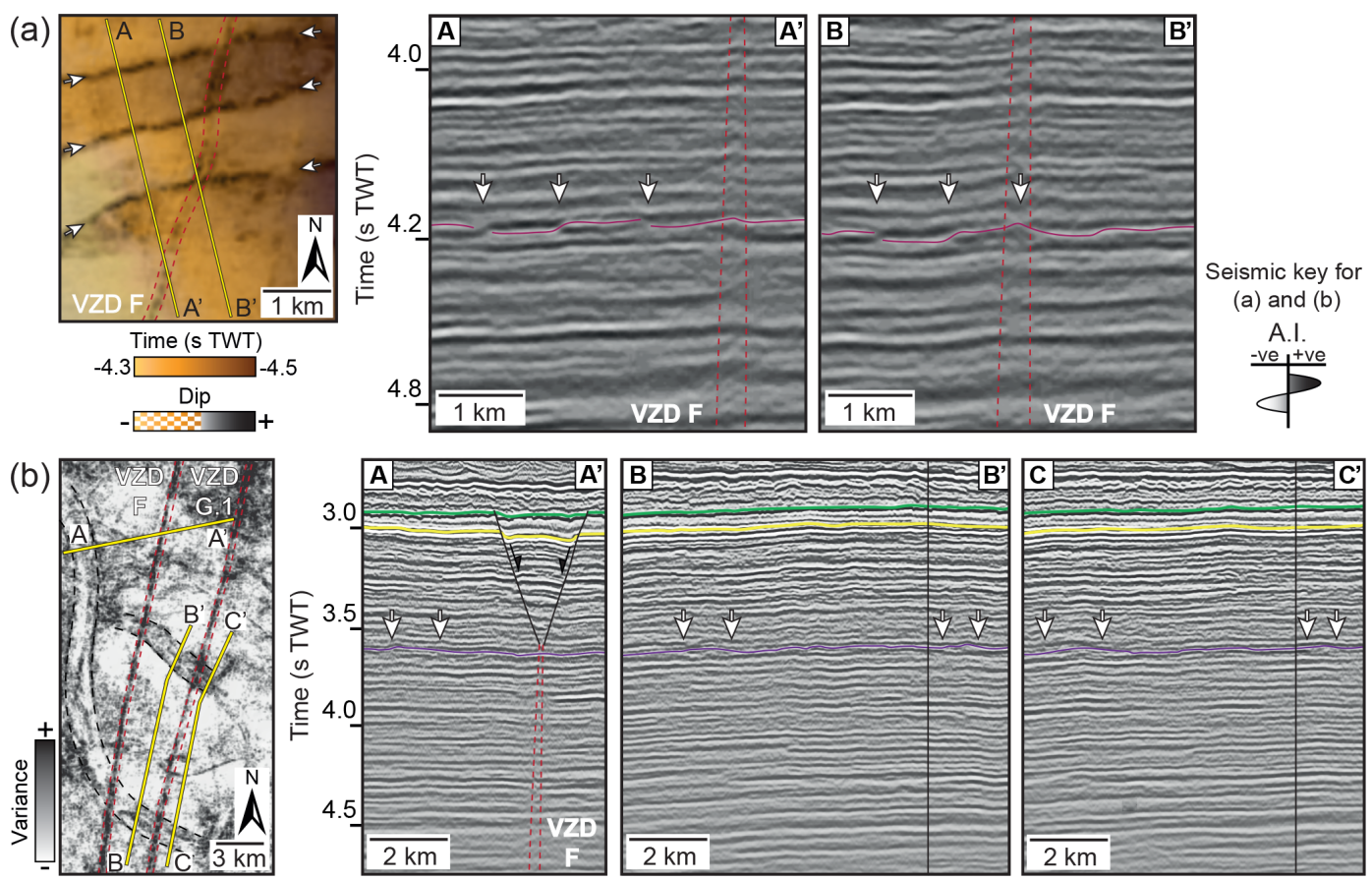

Figure 8. (a) Two-way time structure map and seismic sections showing linear structures (e.g. possible fluvial channel boundaries) within the Mungaroo Formation that are cross-cut but not laterally or vertically offset by VZD F. The structure map is of the stratigraphic horizon interpreted in the seismic sections. (b) Variance map and seismic sections showing fluvial channels within the Mungaroo Formation are cross-cut but not laterally or vertically offset by the VZD F. The variance map is of the stratigraphic horizon interpreted in the seismic sections. See Fig. 4c for locations of (a) and (b).

appear to terminate or extend beneath the survey limit (e.g. Figs. 6 and 7). Although we cannot determine whether the observed lower tips of the VZDs truly mark the base of the structure they correspond to, our data suggests VZD heights are typically $1.5 \pm 0.05 \mathrm{~s}$ TWT $(3.5 \pm 0.35 \mathrm{~km})$ and potentially $3 \pm 0.05$ s TWT $(9 \pm 0.9 \mathrm{~km})$ in places (e.g. Figs. 6 and 7$)$. Only on a few seismic sections, where data quality is high, do we observe undisturbed reflections directly beneath a VZD, thereby allowing us to constrain its height (e.g. Fig. 6c). For example, the depth to the base of VZD E appears to decrease northwards from $5.8 \pm 0.05 \mathrm{~s}$ TWT to $\sim 4.4 \pm 0.05 \mathrm{~s}$ TWT $(\sim 8.5 \pm 0.85-5.6 \pm 0.56 \mathrm{~km})$ (e.g. Fig. 6a-c).

The thickness $(t)$ of the VZDs ranges from $68 \pm 50$ to $335 \pm 50 \mathrm{~m}$ (Fig. $11 \mathrm{~b}$; Table S4). In places, $t$ could not be confidently measured, because other structures (e.g. tectonic faults) locally inhibit VZD imaging. We note that $t$ varies between different 3D seismic datasets, each of which had different acquisition geometries, processing histories, and data quality (Fig. 11b). Regardless of these relatively shortwavelength changes in $t$, there is an apparent overall reduction in $t$ northwards marked by a weakly negative trend line for the combined dataset (Fig. 11b). Cumulatively, $t$ broadly decreases northwards from $\sim 1.2$ to $0.2 \mathrm{~km}$ (Fig. 11b).

Spacing $(h)$ between individual VZDs is variable across the measured transects but broadly increases northwards and is best described by either a log-normal or negative- exponential distributions (Fig. 11c and d; Table S4). For example, $h$ between VZDs D-E and G-H increases northwards from $\sim 2.77 \pm 0.05 \mathrm{~km}$ to $4.90 \pm 0.05 \mathrm{~km}$ and $\sim 6.17 \pm$ $0.05 \mathrm{~km}$ to $11.60 \pm 0.05 \mathrm{~km}$, respectively (Fig. 11c). A prominent exception to this spatial trend in $h$ is the northwards reduction in $h$ between VZDs C-D from $\sim 6.80 \pm 0.05$ to $3.29 \pm 0.05 \mathrm{~km}$ (Fig. 11c). For part of the lengths of VZDs $\mathrm{B}-\mathrm{D}$ and $\mathrm{B}-\mathrm{E}, h$ also decreases northwards, although this is a function of the different orientations of $B$ relative to the other two VZDs (Figs. 4 and 11c). Between physically unconnected VZD sections (e.g. G.1-G.6), $h$ is $2.01 \mathrm{~km}$, with a minimum of $\sim 0.31 \pm 0.05 \mathrm{~km}$ (Fig. 11c). Superimposed onto the large-scale variations in $h$ are localised increases in $h$ (Fig. 11c). The boundaries of these localised increases in $h$ typically coincide with zones where physically unconnected VZD parts terminate or where VZDs contain a short segment with a markedly different trend to its neighbouring segments (Figs. 4 and 1c). There is a good fit between $h$ and log-normal and negative exponential distributions, but the fit of $h$ to normal and power-law distributions is poorer (Fig. 11d).

\subsection{Structures associated with VZDs}

Overlying and parallel to most VZDs are either one or two large (up to $\sim 170 \mathrm{~km}$ long) normal fault systems which dip towards and typically converge on the uppers tips of the 


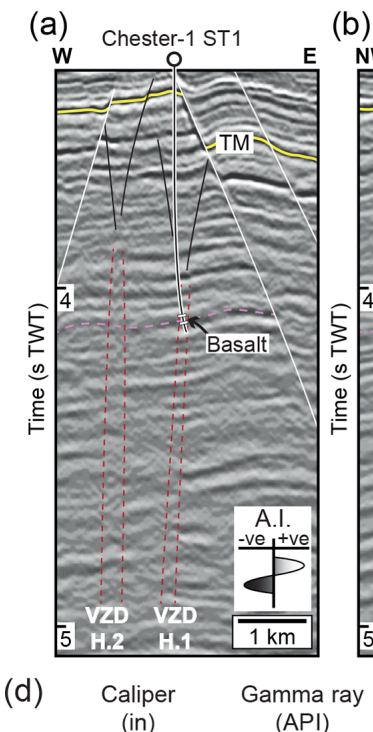

(b)

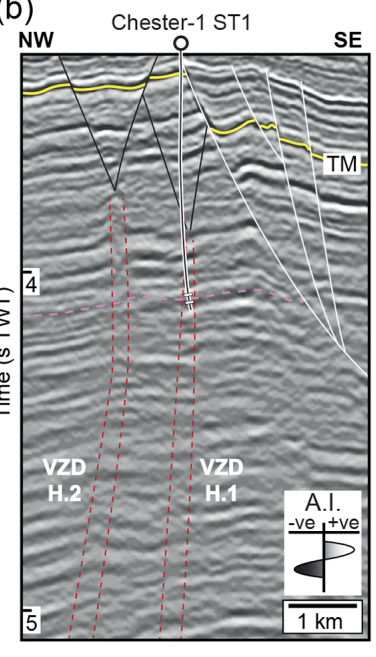

(c)

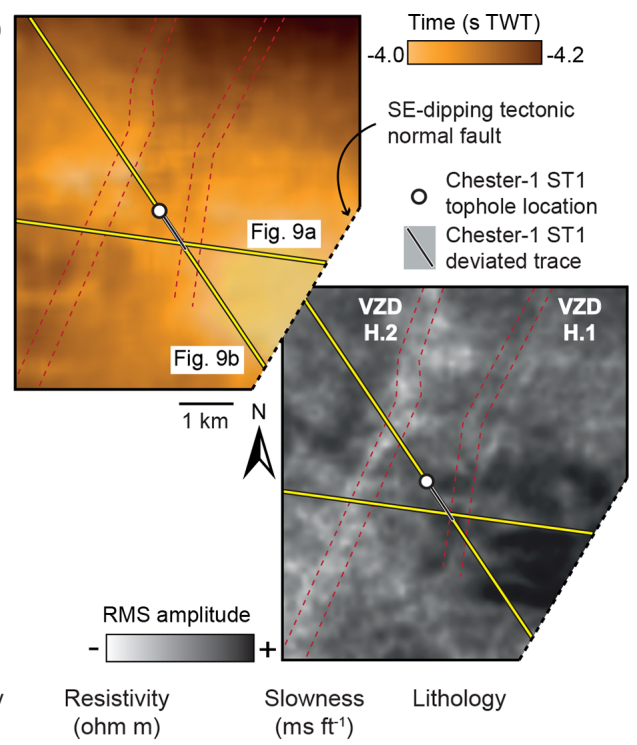

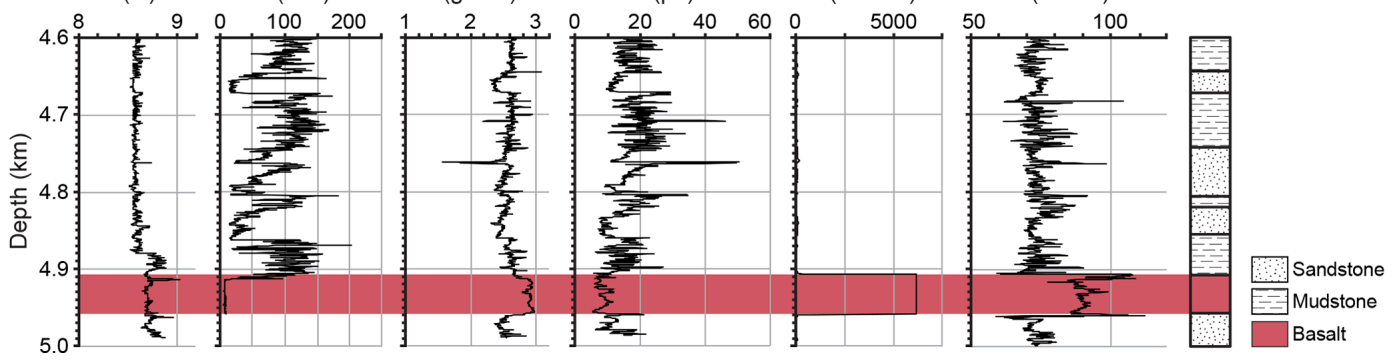

Figure 9. (a-b) Interpreted seismic sections showing the deviated trace of well Chester-1 ST1 intersecting VZD H.1. Also highlighted are the top and base of the basalt interval intersected, and its corresponding seismic horizon. See Fig. 6 for key and Fig. 9c for line locations. Uninterpreted sections provided in Fig. S7. (c) Two-way time structure and root-mean squared (rms) amplitude maps for the horizon corresponding to where Chester-1 ST1 intersects the basalt interval. See Fig. 4c for location. (d) Well log and lithological data from Chester-1 ST1 (Childs et al., 2013).

VZDs (e.g. Figs. 6, 7, and 12). In plan view, these broadly linear normal fault systems extend along much of the length of the underlying VZD (Fig. 12). The normal fault systems commonly comprise multiple low-throw $(0.2 \pm 0.05 \mathrm{~s}$ TWT; $160 \pm 0.16 \mathrm{~m}$ ) faults that are up to $\sim 24 \mathrm{~km}$ long (Figs. 6, 7, and 12). Only four VZDs (K, L, M, and O), as well as southern portions of VZDs H, G, and $\mathrm{U}$, are not overlain by normal fault systems (Fig. 12); this apparent absence of faults may be real or could be because much larger tectonic normal faults are inhibiting the imaging of smaller VZD-related structures. Individual faults within the larger systems extend upwards from the tops of VZDs and terminate within Late Jurassic-toEarly Cretaceous strata, bounding graben of half graben (e.g. Figs. 6 and 7). Laterally restricted antithetic and synthetic normal faults occur within these graben and half graben (e.g. Figs. $6 \mathrm{a}$ and $7 \mathrm{~b}-\mathrm{c}$ ). The youngest stratigraphic horizon offset by the majority of VZD-related normal faults is the near Base Cretaceous unconformity $(\sim 148 \mathrm{Ma})$, although some faults appear to extend upwards into and link with a polygonal fault tier within the Barrow Group (e.g. Figs. 6 and 7).
Sub-circular depressions occur within the graben and half graben overlying the VZDs (Figs. 12 and 13). These depressions are located at the near Base Cretaceous unconformity or at slightly deeper stratigraphic levels within the Dingo Claystone (e.g. Figs. 6a, e; 7b; and 13). The depressions are up to $\sim 0.5 \mathrm{~km}$ wide, $50 \pm 50 \mathrm{~ms}$ TWT $(80 \mathrm{~m})$ deep, and infilled by overlying strata (e.g. Figs. 6a, e, 7b, 12, and 13). Sub-vertical pipes, within which seismic reflections are displaced downwards relative to their regional trend, underlie each depression (e.g. Figs. 6a, e, 7b, and 13). These pipes extend down to the underlying VZD tip or terminate within the Mungaroo Formation above the corresponding VZD (e.g. Figs. 6a, e, 7b, and 13).

\section{Interpretation}

The VZDs define a "swarm" of up to $\sim 171 \mathrm{~km}$ long, relatively thin $(<335 \pm 50 \mathrm{~m}$ wide), sub-vertical, sub-planar zones (Figs. 4-7). These zones cross-cut and disrupt the continuity and amplitude of stratigraphic reflections within the Mungaroo Formation and likely older sedimentary sequences 
(a)
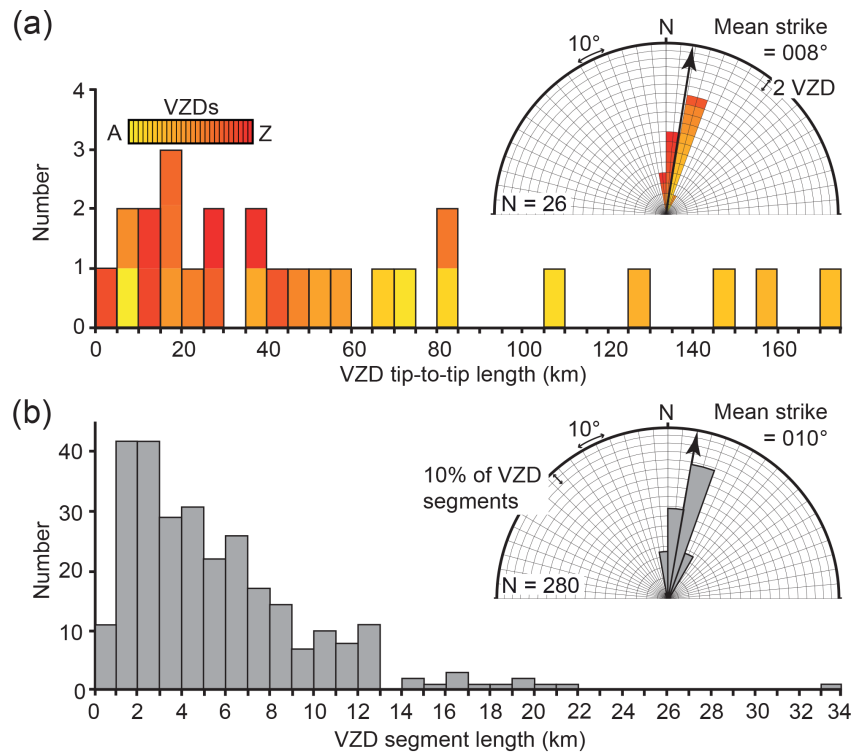

(c)

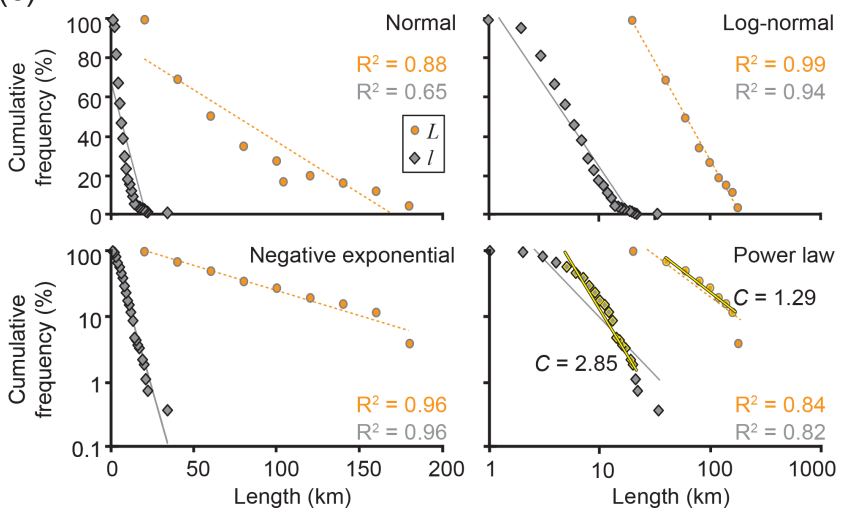

Figure 10. (a) Plot of VZD line length and rose diagram of VZD tip-to-tip strike. (b) Plot of VZD segment length and rose diagram of VZD segment strike. (c) Cumulative frequency plots of VZD line length $(L)$ and segment length $(l)$ to assess whether data fits normal, log-normal, negative-exponential, or power-law distributions. Bestfit trend lines for both datasets reveal they conform with log-normal or negative-exponential distributions. If the curved sections of the data distribution on the power-law plot are discounted, the VZD $L$ and $l$ data display a straight line with a populationexponent (C) of 1.29 and 2.85 , respectively.

(Figs. 5-7). We are confident that the VZDs are not the manifestation of geophysical artefacts but are instead real geological features given that they (i) occur across multiple 2D and 3D seismic datasets with different acquisition and processing histories (e.g. Figs. 4-7; Table S1) and (ii) are oblique to the inline and cross-line directions of the 3D seismic surveys, and thus they do not represent an acquisition footprint (Fig. 4; Table S1). Where similar VZDs have been recognised in other seismic reflection datasets, they have been shown to correlate with either the presence of fluid escape conduits (e.g. Jamtveit et al., 2004; Moss and Cartwright, 2010; Cartwright and Santamarina, 2015), strike-slip faults (a)
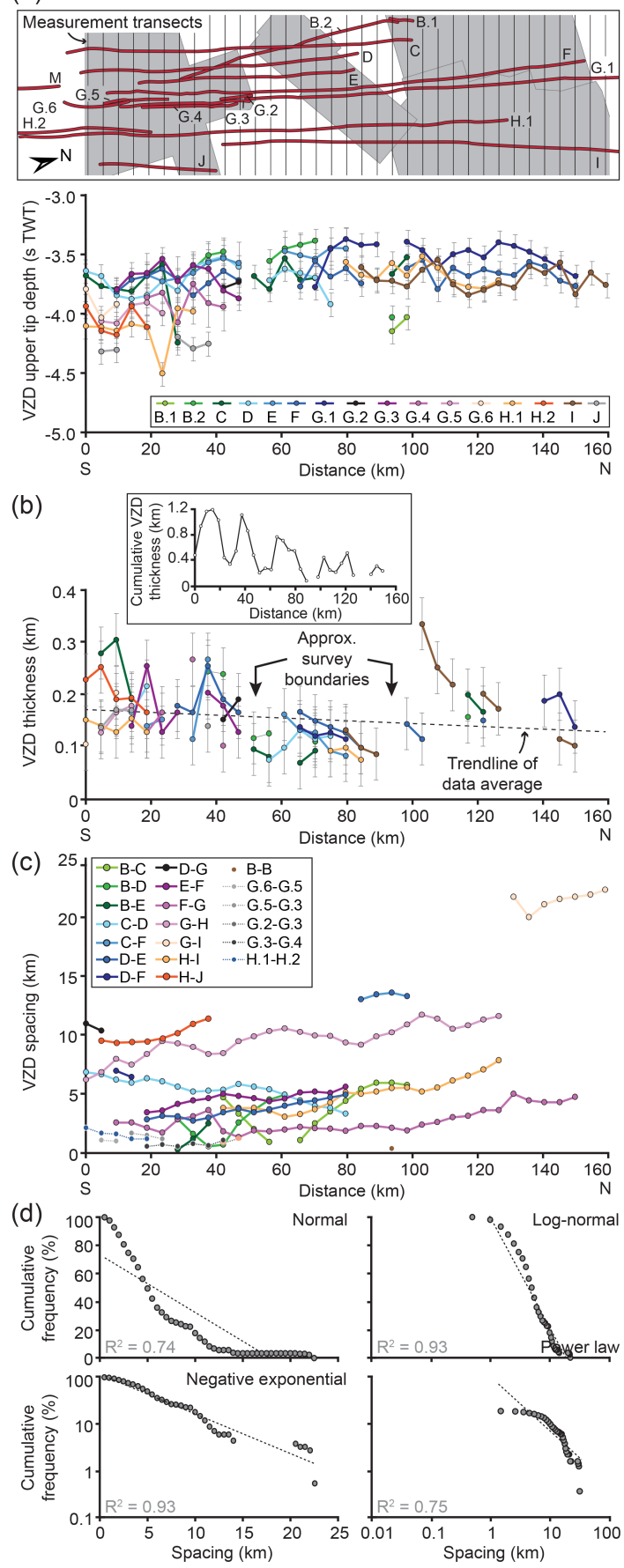

Figure 11. (a) Plot highlighting VZD upper tip depth, measured along transects shown in the inset map, which remains relatively consistent between $4.5 \pm 0.45$ to $3.4 \pm 0.34 \mathrm{~s}$ TWT from south to north. Error bars are $\pm 10 \%$. (b) Plot depicting how VZD thickness changes from south to north. Error bars are $\pm 50 \mathrm{~m}$. Approximate (approx.) location of boundaries between the 3D seismic surveys are shown. Inset: plot of cumulative VZD thickness across each transect. (c) Plot depicting how VZD spacing changes from south to north. Error bars are smaller than data symbols. (d) Cumulative frequency plots showing VZD spacing is best described by a negative-exponential distribution. 

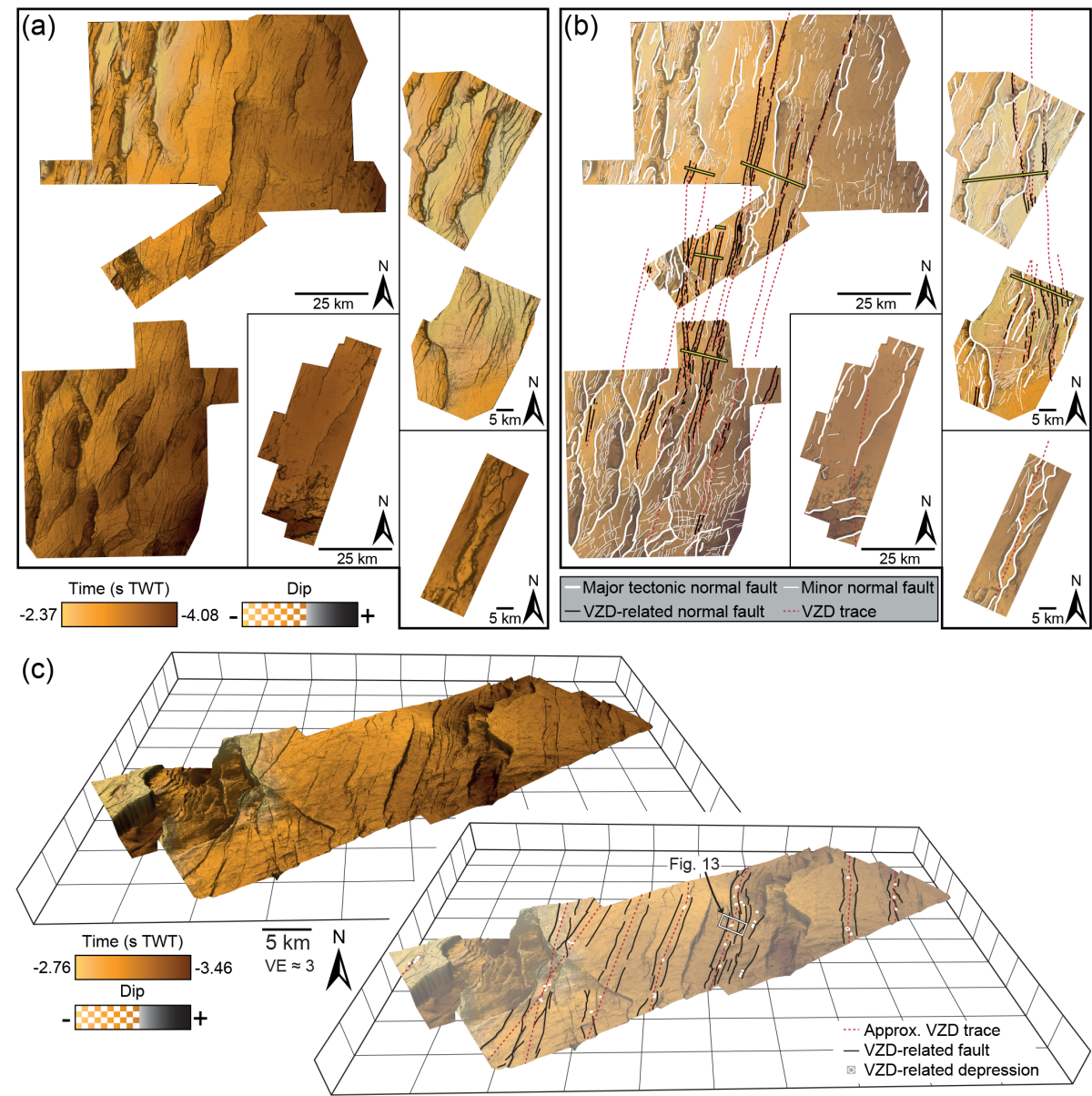

Figure 12. (a-b) Uninterpreted and interpreted time-structure maps showing that faults developed along the near Top Mungaroo Formation relative to the location of underlying VZD traces. Yellow bars in (b) correspond to seismic section locations in Figs. 6 and 7; see Fig. 4d for section labels. For clarity, down-throw markers are omitted. (c) Uninterpreted and interpreted 3D view of the near Top Mungaroo Formation in the Chando 3D survey. For clarity, only VZD-related normal faults are interpreted, in addition to underlying VZD traces and sub-circular depressions (i.e. VZD-related pits).

(Harding et al., 1985; Harding, 1985; Lemiszki and Brown, 1988; Schweig III et al., 1992), or igneous dykes (e.g. Kirton and Donato, 1985; Wall et al., 2010; Ardakani et al., 2017; Holford et al., 2017; Minakov et al., 2018; Plazibat et al., 2019).

We discount fluid escape as an origin for our VZDs because these events produce laterally restricted pipe-like conduits that are geometrically very different to the elongate planar features we observe here (Fig. 4) (e.g. Jamtveit et al., 2004; Moss and Cartwright, 2010; Cartwright and Santamarina, 2015). We also demonstrate that fluvial channels and linear structures within the Mungaroo Formation are not vertically or laterally offset by cross-cutting VZDs (e.g. Figs. 5 and 8), indicating that there is no evidence for strike- or dipslip motion across the latter (cf. Harding, 1985). Plate reconstructions for the time of break-up between Greater India and Australia in the Late Jurassic to Early Cretaceous, informed by the orientation of tectonic normal faults, seafloor spreading anomalies, and the Cape Range Fracture Zone, further suggest that rifting was margin-parallel and thus unlikely to involve significant $\sim \mathrm{N}$-trending strike-slip faulting (e.g. Heine and Müller, 2005). We therefore consider it unlikely that the VZDs are faults.

We interpret the VZDs as igneous dykes because (i) their seismic expression appears similar to dykes in other real and synthetic seismic datasets (cf. Figs. 2, 6, and 7) (e.g. Kirton and Donato, 1985; Wall et al., 2010; Ardakani et al., 2017; Holford et al., 2017; Eide et al., 2018; Minakov et al., 2018; Plazibat et al., 2019) and (ii) the geometry of individual VZDs, as well as that of the array they comprise, are akin to the morphology of dyke swarms exposed at Earth's surface (cf. Figs. 1a-b and 4) (e.g. Halls, 1982; Ernst et al., 2001; Jowitt et al., 2014). The $\sim 48 \mathrm{~m}$ thick basalt interval intersected by the Chester-1 ST1 well, which occurs within VZD H.1, may further support our interpretation that the VZDs correspond to igneous dykes (Fig. 9). However, 
Table 1. VZD length and strike data.

\begin{tabular}{|c|c|c|}
\hline Name & $\begin{array}{r}\text { Length } \\
(L) \\
(\mathrm{km})\end{array}$ & $\begin{array}{r}\text { Strike } \\
(S) \\
\left({ }^{\circ}\right)\end{array}$ \\
\hline A & 007.1 & 021 \\
\hline $\mathrm{B}^{*}$ & 074.1 & 002 \\
\hline $\mathrm{C}$ & 106.4 & 014 \\
\hline $\mathrm{D}$ & 084.5 & 012 \\
\hline $\mathrm{E}$ & 066.4 & 012 \\
\hline $\mathrm{F}$ & 147.0 & 012 \\
\hline $\mathrm{G}^{*}$ & 170.7 & 013 \\
\hline $\mathrm{H}^{*}$ & 157.0 & 014 \\
\hline I & 125.8 & 017 \\
\hline $\mathrm{J}$ & 035.9 & 014 \\
\hline $\mathrm{K}$ & 054.1 & 004 \\
\hline $\mathrm{L}$ & 056.4 & 020 \\
\hline M & 017.0 & 017 \\
\hline $\mathrm{N}$ & 008.6 & 012 \\
\hline $\mathrm{O}$ & 048.2 & 012 \\
\hline $\mathrm{P}$ & 021.1 & 175 \\
\hline Q & 082.7 & 178 \\
\hline $\mathrm{R}$ & 019.0 & 175 \\
\hline $\mathrm{S}$ & 017.9 & 002 \\
\hline $\mathrm{T}$ & 027.3 & 005 \\
\hline $\mathrm{U}$ & 042.5 & 017 \\
\hline $\mathrm{V}$ & 003.5 & 007 \\
\hline W & 013.1 & 001 \\
\hline$X$ & 013.5 & 004 \\
\hline $\mathrm{Y}$ & 037.7 & 173 \\
\hline $\mathrm{Z}$ & 027.6 & 001 \\
\hline
\end{tabular}

to attribute the recovered basalt cuttings to a dyke, we first need to assess whether the well could instead have penetrated a lava flow or sill. Based on an interval velocity of $\sim 4.7 \pm 0.5 \mathrm{~km} \mathrm{~s}^{-1}$ and a dominant frequency of $\sim 20 \mathrm{~Hz}$ around the intersected basalt, we calculate that the limits of separability and visibility are locally $\sim 59 \pm 6$ and $\sim 8 \pm 1 \mathrm{~m}$, respectively. Given these limits of separability and visibility, coupled with the higher density and seismic velocity of the basalt compared to the surrounding sedimentary rocks (Fig. 9d), a $\sim 48 \mathrm{~m}$ thick lava flow or sill should be seismically expressed as a high-amplitude, positive polarity, tuned reflection package (e.g. Eide et al., 2018; Rabbel et al., 2018). Yet the intra-Mungaroo seismic reflection coincident with the basalt in Chester-1 ST1 has a negative polarity and is of moderate amplitude (Fig. 9a and b). These observations suggest the basalt intersected by Chester-1 ST1 does not come from a lava flow or sill but instead supports our interpretation that the coincident VZD H.1, and likely other VZDs, are igneous dykes.

Our interpretation that the VZDs correspond to igneous dykes raises the question as to whether the observed overly-

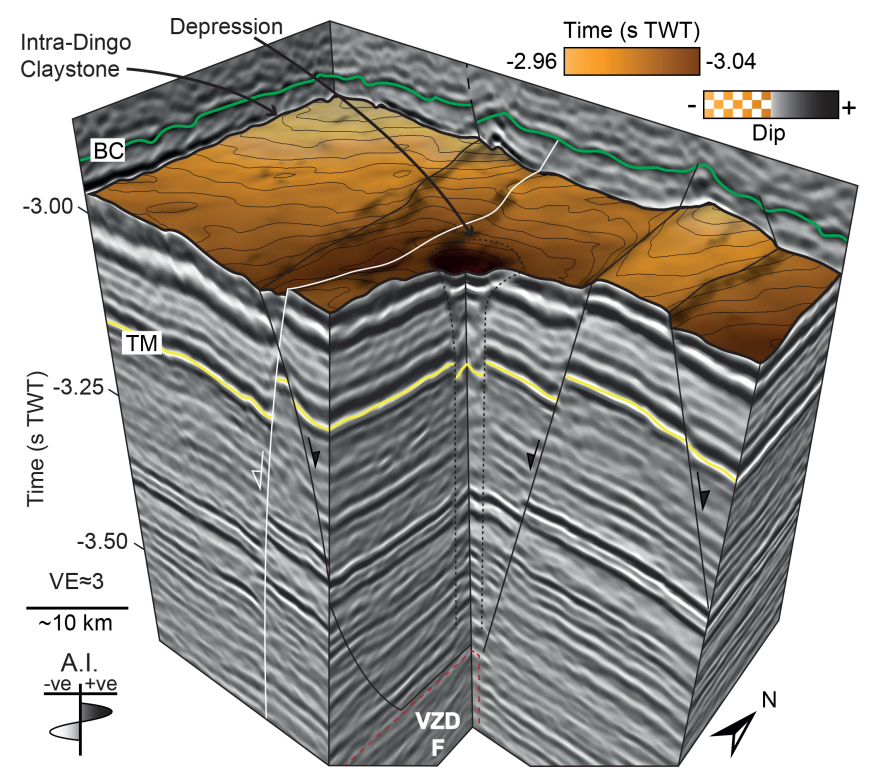

Figure 13. 3D view of the top of a sub-circular depression, developed above VZD F, expressed on an Intra-Dingo Claystone horizon. The sub-circular depression is underlain by a vertical pipe-like structure, which extends down to VZD F and contains stratigraphic reflections that are offset downwards relative to their regional trend.

ing normal fault systems and pipes, which converge on the inferred dykes, were genetically related to magmatism (e.g. Figs. 4, 6, 7, 12, and 13). For example, normal fault systems and sub-circular depressions similar to those we describe have been observed above dykes on Earth, other planetary bodies, and in physical and numerical models (e.g. Pollard et al., 1983; Rubin and Pollard, 1988; Rubin, 1992; Okubo and Martel, 1998; Wilson and Head, 2002; Wyrick et al., 2004; Wyrick and Smart, 2009; Trippanera et al., 2015a, b; Hardy, 2016). Numerical and analytical models suggest normal faulting above intruding and widening dykes is driven by the concentration of tensile stress at the dyke's upper tip and at the contemporaneous surface (e.g. Pollard et al., 1983; Rubin and Pollard, 1988; Rubin, 1992). Shear failure within this local dyke-induced stress field produces grabenor half-graben-bounding dyke-parallel normal faults that dip towards and converge on the dyke's upper tip (e.g. Pollard et al., 1983; Rubin and Pollard, 1988; Rubin, 1992; Trippanera et al., 2015b); these faults are termed "dyke-induced normal faults". Dyke intrusion and widening can also locally produce cavities through the accumulation and release of magmatic volatiles at its upper tip or the heating and escape of pore fluids in the immediately overlying host rock (e.g. Wilson and Head, 2002; Mège et al., 2003; Wyrick et al., 2004). Collapse of these cavities produces overlying pipe-like zones of subsidence expressed at the contemporaneous surface as sub-circular depressions called "pit craters" (e.g. Wilson and Head, 2002; Mège et al., 2003; Wyrick et al., 2004). Due to their spatial coincidence with underlying 
dykes, and given their geometrical similarities to supra-dyke structures observed elsewhere, we suggest the faults and depressions described here are dyke-induced normal fault systems and pit craters (Figs. 5, 7, 12, and 13) (e.g. Pollard et al., 1983; Rubin and Pollard, 1988; Rubin, 1992; Okubo and Martel, 1998; Wilson and Head, 2002; Wyrick et al., 2004; Wyrick and Smart, 2009; Trippanera et al., 2015a, b; Hardy, 2016).

\section{Discussion}

\subsection{Timing of dyke emplacement}

Radiometric dates are unavailable to constrain the emplacement age of the studied dykes, so we have to apply seismic stratigraphic techniques. Each dyke intrudes and terminates within the Mungaroo Formation, indicating that their emplacement occurred during or after the Triassic (e.g. Figs. 6, and 7). The dykes also cross-cut and thus post-date sills intruded within the Triassic Mungaroo Formation (e.g. Fig. 6b, c, and f). Although we have no constraints on the age of these sills cross-cut by the dykes, it is likely they were emplaced during a regional phase of Late Jurassic-to-Early Cretaceous magmatism (e.g. Symonds et al., 1998; Magee et al., 2013a, b, 2017; Rohrman, 2013). Onlap of overlying strata onto intrusion-induced forced folds suggests that sill emplacement elsewhere in the North Carnarvon Basin may have begun in the Kimmeridgian (Magee et al., 2013a, 2017).

The near Base Cretaceous unconformity $(\sim 148 \mathrm{Ma})$ is the youngest stratigraphic horizon deformed by most of the interpreted dyke-induced normal fault systems and pit craters (e.g. Figs. 6 and 7). Where dyke-induced normal fault systems and pit craters are observed elsewhere on Earth or other planetary bodies, they deform the surface contemporaneous with dyke intrusion (e.g. Pollard et al., 1983; Rubin and Pollard, 1988; Rubin, 1992; Okubo and Martel, 1998; Wilson and Head, 2002; Wyrick et al., 2004; Wyrick and Smart, 2009; Trippanera et al., 2015a, b; Hardy, 2016). Our seismic stratigraphic observations therefore suggest that the near Base Cretaceous unconformity ( $\sim 148 \mathrm{Ma}$ ) likely marked the palaeosurface during dyking, indicating emplacement principally occurred during or after its development but ceased before the overlying Barrow Group was deposited. Some pit craters terminate within rather than at the top of the Dingo Claystone (e.g. Fig. 13), suggesting dyking may have initiated in the Late Jurassic before the near Base Cretaceous unconformity formed at $\sim 148 \mathrm{Myr}$. The apparent extension of some dyke-induced normal faults into the $\sim 146.7-138.2 \mathrm{Ma}$ Barrow Group, which is located above the near Base Cretaceous unconformity, may be indicative of renewed postValanginian dyking (Figs. 6d, e, and 7a-c). An alternative suggestion is that the upward extension of the dyke-induced normal faults into the Barrow Group simply reflects fault reactivation and/or dip linkage during later polygonal fault formation (i.e. these fault extensions are unrelated to dyking). Such reactivation or dip linkage of the dyke-induced normal faults is supported by the (i) reduced dip of many dyke-induced fault segments above the near Base Cretaceous unconformity (e.g. Figs. 6d, e, and 7a-b) and (ii) similar extension of some tectonic normal faults above the near Base Cretaceous unconformity, occasionally to just below the seabed. Overall, we propose that all dykes were likely intruded during a short period in the Late Jurassic, probably during the Tithonian ( 152-147 Ma), before the onset of Barrow Group deposition at $\sim 146.7 \mathrm{Ma}$ (Reeve et al., 2016); we name this newly discovered suite of igneous dykes the Exmouth Dyke Swarm.

\subsection{Dyke swarm structure}

To understand the kinematics and mechanics governing dyke swarm emplacement, we typically rely on measuring the geometrical properties (e.g. horizontal length, thickness, and spacing) of dykes exposed at the Earth's surface (e.g. Gudmundsson, 1983; Jolly and Sanderson, 1995; Paquet et al., 2007). A potential problem with these analyses is that we can only measure the surface, principally 2D expression of dykes and dyke swarms, which may not equal their true 3D geometry. For example, seismic reflection data from offshore southern Norway reveal the width of an imaged dyke swarm increases with depth, implying the dimensions of dyke swarms measured at the surface depend partly on erosion level and may therefore not capture the true swarm geometry (Phillips et al., 2018). Seismic reflection data thus provide a unique opportunity to examine and quantify the $3 \mathrm{D}$ structure of a dyke swarm independent of the potential bias introduced by the processes (e.g. erosion) controlling how dyke swarms intersect the surface. Whilst seismic reflection data can provide unprecedented insights into the 3D structure of dyke swarms, limitations and uncertainties in seismic and/or borehole data quality, resolution, and depth conversion make it difficult to relate the quantifiable VZD seismic expression to the true geometry of the dykes they likely represent. For example, we cannot resolve whether a mapped VZD, even if it is intersected by a borehole (e.g. Fig. 9), corresponds to a single dyke or multiple closely spaced intrusions. Here, we specifically discuss how our VZD measurements can be used to evaluate how dyke length, thickness, and spacing may compare to predicted distributions of these geometrical properties derived from surface studies and physical, numerical, and analytical modelling-based studies.

\subsubsection{Horizontal dyke length}

Lateral lengthening of fractures is commonly facilitated by linkage between individual segments (e.g. Gudmundsson, 1987; Cladouhos and Marrett, 1996; Schultz, 2000; Mège and Korme, 2004). The evolution of a fracture population can be unravelled from its length distribution if we can as- 
certain whether linked or closely spaced fractures should be treated as one or several structures (e.g. Schultz, 2000; Mège and Korme, 2004); i.e. does the length-frequency distribution of a fracture population change through time in response to linkage modifying the behaviour of the system or is it scale invariant? Dykes are magma-filled fractures and can broadly be considered to intrude instantaneously and independently formed fractures (i.e. they do not interact), implying the length-frequency distribution of a dyke swarm should preserve the initial configuration of the fracture population (Mège and Korme, 2004). Comparing data from fracture and dyke populations reveals that their length-frequency distributions are both broadly power-law distributions, suggesting that a mechanical linkage of fractures does not modify system behaviour (e.g. Gudmundsson, 1987; Cladouhos and Marrett, 1996; Schultz, 2000; Mège and Korme, 2004; Paquet et al., 2007). Here we use our data, assuming the dykes are "Mode I" fractures, to examine whether (i) the measurement of dyke-surface intersections introduces bias to lengthfrequency distributions and (ii) dyke segmentation, which may be indicative of non-instantaneous and non-independent fracture growth, also displays a power-law length-frequency distribution (cf. Mège and Korme, 2004).

Cumulative length-frequency plots for all measured horizontal dyke lengths $(L)$, which comprise connected and/or closely spaced but physically unconnected segments, initially appear to fit a log-normal or negative exponential distribution rather than a power-law distribution (Fig. 10c) (cf. Mège and Korme, 2004; Paquet et al., 2007). Dyke segment horizontal length $(l)$ data display similar log-normal and negative exponential distribution characteristics (Fig. 10c). However, power-law distributions can be fit to $L$ values between 20 and $160 \mathrm{~km}$ and $l$ values of $5-20 \mathrm{~km}$ (Fig. 10c). The population exponents $(C)$ for the $L$ and $l$ datasets are 1.29 and 2.85 , respectively, consistent with values derived from the analysis of other fracture and dyke populations (Fig. 10c) (see Mège and Korme, 2004 and references therein). The observed departure of our measured $L$ and $l$ values from a power-law distribution at small and large length scales could indicate bias in the data. For example, restrictions in dyke imaging and 2D seismic line spacing may mean that (i) the dykes are likely longer than mapped; (ii) some dykes (e.g. VZDs X and Z) may be connected along-strike, thereby increasing their lateral length (Figs. 4b-d); and (iii) small dykes and/or dyke segments are difficult to recognise or may not be imaged, because they occur between 2D seismic lines outside of areas imaged by the 3D surveys. We contend that our data could thus be considered consistent with previous studies in describing dyke length distributions as power-law distributions, indicating that processes controlling dyke length (e.g. segmentation) are scale invariant (Mège and Korme, 2004). Furthermore, our results suggest that the free-surface intersection of fractures or dykes is, at least typically, representative of a population's length distribution.

\subsubsection{Dyke thickness and crustal extension}

The thickness of a dyke, or cumulative thickness of a dyke swarm, influences a variety of processes, including eruption rates and crustal extension (e.g. Krumbholz et al., 2014). For example, statistical analyses of dyke thickness distributions derived from surface-based measurements inform dynamic models of dyke emplacement, shedding light on the processes controlling dyke thickness (e.g. Jolly and Sanderson, 1995; Klausen, 2004, 2006; Krumbholz et al., 2014). Resolving the 3D structure of dyke swarms in seismic reflection data provides an opportunity to examine both lateral and vertical variations in dyke thickness distribution. We show individual VZD thicknesses measured across multiple 3D seismic surveys range from $335 \pm 50$ to $68 \pm 50 \mathrm{~m}$ and gradually decrease northwards (Fig. 11b). Furthermore, although there are gaps in our thickness measurements where VZD imaging is locally inhibited, we estimate that cumulative VZD thickness across our selected transects also decreases northwards from $\sim 1.2$ to $0 \mathrm{~km}$ (Fig. 11b). Because the northwards decrease in VZD thickness is consistent across multiple seismic surveys, which each have different acquisition and processing parameters, we suggest this trend could mark a similar northwards decrease in true dyke thickness (Fig. 11b). However, synthetic seismic forward models suggest that the thickness of VZDs corresponding to sub-vertical dykes is greater than the true dyke thickness (Eide et al., 2018). Furthermore, because VZD thickness is partly controlled by the acquisition and processing properties of the seismic reflection data in which they are imaged in (e.g. frequency; Eide et al., 2018), evidenced by the marked differences in VZD thickness between different seismic surveys (Fig. 11b), it is difficult to determine how VZD thickness and true dyke thickness are related. Using observations from the Chester1 ST1 well, which likely intersects a $48 \mathrm{~m}$ long section of basalt dyke, we calculate that the dyke has a true thickness of $\sim 18 \mathrm{~m}$, assuming its orientation is parallel to that of the $\sim 130 \pm 50 \mathrm{~m}$ wide VZD it relates to in Fig. 14. These well data confirm synthetic seismic forward model predictions that dyke-related VZD thickness is, in at least some cases, much greater than true dyke thickness (Eide et al., 2018). Based on the dyke thickness constrained by Chester-1 ST1 and its corresponding VZD expression and if we consider all VZDs have a thickness ratio to true dyke thickness of at least $7: 1$, we estimate dyke thicknesses measured across our selected transects range from $\sim 47 \pm 6$ to $\sim 10 \pm 6 \mathrm{~m}$; we note that we cannot distinguish whether the VZDs correspond to single dykes or multiple dykes. These dyke thickness values are closer to, although typically still larger than, dyke thickness distributions measured in onshore examples where most dykes are $0-10 \mathrm{~m}$ thick, potentially up to $20-40 \mathrm{~m}$ thick (e.g. Gudmundsson, 1983; Jolly and Sanderson, 1995; Mège and Korme, 2004; Klausen, 2006; Kavanagh and Sparks 2011; Krumbholz et al., 2014). Because dykes are commonly accommodated by host rock dilation, their thicknesses are a 


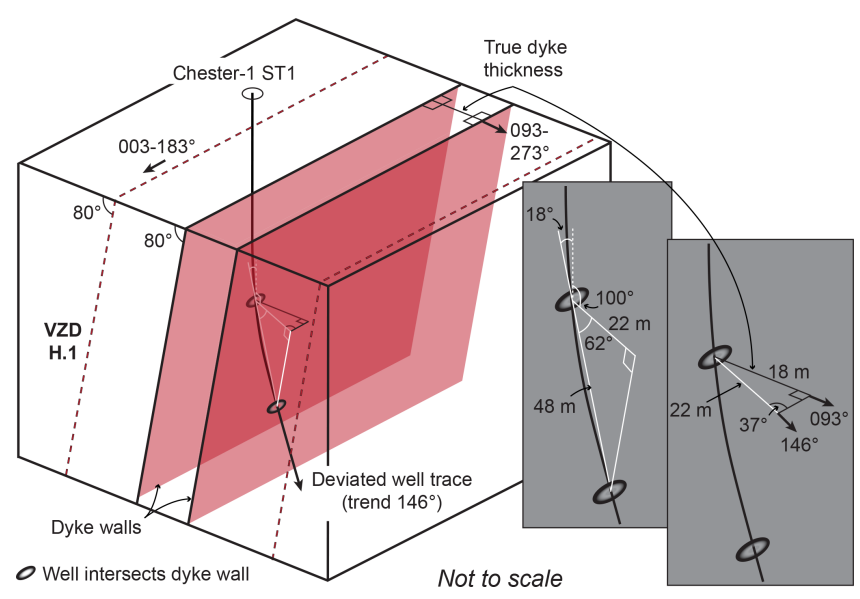

Figure 14. Schematic showing how the deviation inclination and direction of the Chester-1 ST1 borehole can be used to estimate true dyke thickness assuming the dyke walls are parallel to the VZD H.1 boundaries. By taking the intersected thickness ( $48 \mathrm{~m}$ ) of the dyke and the inclination of the SE-dipping deviated well trace ( $18^{\circ}$ from vertical), relative to the W-dipping $\left(80^{\circ}\right) \mathrm{VZD}$, we can use trigonometry to determine that the distance between the dyke wall and well intersections, on a plane orthogonal to the dyke walls (i.e. $100^{\circ}$ from vertical), is $22 \mathrm{~m}$. This information, coupled with the difference between the VZD strike $\left(093-273^{\circ}\right.$ and well azimuth $\left(146^{\circ}\right)$, allows us to determine the true dyke thickness is $\sim 18 \mathrm{~m}$.

proxy for the amount of syn-emplacement extension of an area (e.g. Jolly and Sanderson, 1995; Marinoni, 2001). We estimate that the cumulative dyke thickness measured across our selected transects decreases northwards from $\sim 170$ to $0 \mathrm{~m}$, which, given that each transect is $\sim 51 \mathrm{~km}$ long and assuming dyke opening was purely dilational, corresponds to an $\sim 0.33 \%-0 \%$ extension; this is a minimum estimate of strain as there are likely numerous dykes present that are not imaged in our seismic reflection data. It is unknown whether this estimated extension of up to $0.33 \%$ accommodated by dyking is applicable to the entire dyke swarm. Further work in understanding how dykes are expressed in seismic reflection data is required before these data can be used to accurately quantify dyke thickness distributions and the role of dyking in extension.

\subsubsection{Dyke spacing}

Plan-view sections through dyke swarms reveal that individual dykes are typically regularly spaced, with the spacing $(h)$ of radiating swarms increasing away from their focal area (e.g. Ernst et al., 1995; Jolly and Sanderson, 1995; Bunger et al., 2013). Identifying controls on $h$ is fundamental to understanding why dykes occur in swarms and thus how they interact with and/or drive crustal extension on Earth and other planetary bodies (Bunger et al., 2013). Analytical predictions suggest first-generation laterally propagating dykes will have energetically optimal spacings that are related to dyke height
$(H)$ and magma source conditions (Bunger et al., 2013). For dykes emanating from a constant pressure magma source (i.e. an infinitely large, compressible reservoir), $h / H$ is expected to be $\approx 1$, whilst those from a constant influx magma source (i.e. a small, incompressible reservoir) will have either a $h / H$ of $\approx 2.5$ or $\approx 0.3$ (Bunger et al., 2013). Constraining the relative age of dykes is critical to testing these analytical predictions, because second-generation dykes or younger may preferentially intrude between first-generation dykes, thereby reducing the apparent spacing (Bunger et al., 2013).

Dyke spacing within the Exmouth Dyke Swarm ranges from $\sim 22.4 \pm 0.05$ to $0.3 \pm 0.05 \mathrm{~km}$, with a geometric mean of $\sim 4.1 \mathrm{~km}$, and it broadly increases northwards (Figs. 4 and 11d). This northward increase in $h$, coupled with apparent northwards reductions in dyke thickness and abundance, implies extension accommodated by the Exmouth Dyke Swarm similarly decreased northwards (Figs. 4 and 11d). To test analytical predictions using our measured $h$ values, it is first important to recognise key limitations in our dataset: (i) not all dykes within the swarm may be imaged by the seismic reflection data, suggesting our $h$ measurements are likely only maximum values; (ii) $H$ is difficult to quantify because a reduction in data quality with depth likely means we cannot accurately pick the lower tips of dykes, some of which may extend beneath the seismic surveys (e.g. Figs. 6 and 7); and (iii) it is challenging to ascertain whether all dykes were emplaced simultaneously or not during the Late Jurassic dyking event. Because the dykes are typically $>1.5 \pm 0.05 \mathrm{~s}$ TWT tall (e.g. Figs. 6 and 7), we use extrapolated check-shot data to estimate that the average $H$ is at least $\sim 3.5 \pm 0.35 \mathrm{~km}$ (Fig. S4). Compared to our current understanding of the different theories of dyke emplacement (Townsend et al., 2017), our minimum height estimate implies that the dykes are encased within sedimentary strata and were emplaced either as (i) ascending dykes of a fixed fluid volume, where upwards migration was balanced by closure at its lower tip (School 1) or (ii) lateral propagation of a dyke with a fixed height (School 3). In contrast, as a maximum estimate for average $H$, we consider the dykes could extend upwards from a source (e.g. the high-velocity body; Rohrman, 2013) towards the base of the crust (e.g. School 2; Townsend et al., 2017), which across the Exmouth Plateau is likely $\sim 20--28 \mathrm{~km}$ beneath the present-day seabed (e.g. Mutter and Larson, 1989; Stagg and Colwell, 1994; Tindale et al., 1998; Stagg et al., 2004; Reeve et al., 2016). Given the upper dyke tips broadly occur at $\sim 3.7 \pm 0.05 \mathrm{~s}$ TWT, equivalent to a depth of $\sim 4.1 \pm 0.41 \mathrm{~km}$, we therefore suggest the maximum average $H$ could be up to $\sim 24 \mathrm{~km}$. Assuming dyking was instantaneous and using the geometric mean for $h(\sim 4.1 \mathrm{~km})$, we calculate $h / H \approx 1.17-0.17$.

The calculated $h / H$ values of $1.17-0.17$ are broadly consistent with and cannot be used to discriminate between the constant pressure $(h / H \approx 1)$ and constant influx $(h / H \approx$ 0.3 ) endmember source conditions (Bunger et al., 2013). However, dyke swarms exposed onshore typically contain 
significantly more dykes than the 26 we identify in our seismic reflection data (cf. Gudmundsson, 1983; Jolly and Sanderson, 1995; Mège and Korme, 2004). If seismically unresolved dykes are present in the study area, we may expect $h$ to be less than that measured and thus more consistent with $h / H \approx 0.3$, implying the dykes were fed from a constant influx magma source (Bunger et al., 2013). Alternatively, if we consider that dyking was incremental, with later dykes intruding host rock between pre-existing intrusions, we would expect $h$ of $4.1 \mathrm{~km}$ for the first-generation dykes; this would imply the original maximum $h / H$ ratio could be $\approx 1$. Potential evidence for incremental emplacement of the Exmouth Dyke Swarm includes (i) the relatively good fit of $h$ to a negative-exponential distribution (Fig. 11e), which suggests $h$ is random and likely results from incorporation of different dyke sets into the data and (ii) the observation that some pit craters occur within (rather than at the top of) the Dingo Claystone (e.g. above Dyke F; Fig. 13), suggesting their associated dykes were emplaced before the formation of the near Base Cretaceous unconformity $(\sim 148 \mathrm{Ma})$. For example, if we hypothetically consider that VZDs C, F, H, and I were emplaced first, their geometric mean $h$ of $12.4 \mathrm{~km}$ implies $h / H \approx 3.54-0.52$, which again could be considered consistent with a constant pressure $(h / H \approx 1)$ or constant influx $(h / H \approx 2.5)$ source (Bunger et al., 2013). Mapping the occurrence and distribution of pit craters formed before the near Base Cretaceous unconformity may allow us to identify first-generation dykes and thereby constrain dyke source conditions.

\subsubsection{Dyke swarm volume}

Although it is difficult to accurately constrain dyke thicknesses and heights using our data, here we use the measured horizontal length $(L)$ of each dyke, an assumed average dyke thickness of $\sim 20 \mathrm{~m}$, and dyke heights of $\sim 3.5-24 \mathrm{~km}$ to estimate dyke volumes (Table 2). If the dykes are relatively short (i.e. $\sim 3.5 \mathrm{~km}$ high), we estimate that dyke volumes range from $\sim 0.5$ to $11.9 \mathrm{~km}^{3}$, whereas if the dykes are relatively tall and extend down to the base of the crust, their volumes may range from $\sim 3.4$ to $81.9 \mathrm{~km}^{3}$ (Table 2). We calculate that the cumulative volume of the mapped dykes ranges from $\sim 102.6$ to $703.2 \mathrm{~km}^{3}$ (Table 2). These are undoubtedly minimum estimates, given the likely presence of sub-seismic dykes.

\subsection{Emplacement of the Exmouth Dyke Swarm}

We mapped the Exmouth Dyke Swarm, as well as associated dyke-induced normal faults and pit craters, across a $\sim 40000 \mathrm{~km}^{2}$ part of the North Carnarvon Basin (Figs. 47 and 12). Long, linear grabens, containing sub-circular depressions, similar to the dyke-induced normal faults and pit craters we identified, occur at the near Base Cretaceous unconformity elsewhere in the North Carnarvon Basin (e.g.
Fig. 15) (Velayatham et al., 2018, 2019). The formation of some of these other depressions has been linked to fluid escape following faulting of overpressured strata and not dyking (Velayatham et al., 2018). However, their geometrical similarity to and occurrence at the same structural level as the dyke-induced normal fault systems and pit craters described here suggests that they could be the palaeosurface expression of the Exmouth Dyke Swarm (cf. Figs. 12 and 15) (see also Velayatham et al., 2019). This potential distribution of dykes (except for VZD K), dyke-induced normal fault systems, and pit craters across the North Carnarvon Basin appears to describe a giant radial dyke swarm (cf. Figs. 1c and 15c) (cf. Halls and Fahrig, 1987; Ernst et al., 1995, 2001; Ernst, 2014). Projecting the inferred dykes to a common focal area, which is located on the Cuvier Margin, suggests the Exmouth Dyke Swarm could be $>500 \mathrm{~km}$ long and distributed around a $\sim 039^{\circ}$ (perhaps up to $\sim 054^{\circ}$ ) arc (Fig. 15c). To unravel the origin of the Exmouth Dyke Swarm, we first discuss evidence for magma propagation direction and synemplacement stress conditions.

\subsubsection{Dyke propagation direction}

The radiating form of the Exmouth Dyke Swarm suggests individual dykes may have been sourced and thus flowed laterally northwards from the northern sector of the Cuvier Margin (Fig. 15c) (see also Velayatham et al., 2019). Lateral propagation of the dykes to the north could be supported by the (i) maintenance of dyke upper tip depths (Figs. 6, 7, and 11a), consistent with the expectation that horizontally emplaced dykes have fixed upper and lower tip positions (e.g. Townsend et al., 2017); (ii) subtle northwards decrease in VZD thickness (Fig. 11b), which we suggest could reflect thinning of dykes, perhaps towards their laterally propagating tip (e.g. Healy et al., 2018); and (iii) minor but abrupt changes in the strike of connected dyke segments (Figs. 4 and 5), which are reminiscent of the kinked geometry attained by the Bárðarbunga-Holuhraun dyke during its possible incremental, lateral propagation (Sigmundsson et al., 2015; Woods et al., 2019).

\subsubsection{Palaeostress conditions during dyke emplacement}

The orientation and structure of dykes and dyke swarms are commonly used to reconstruct syn-emplacement stress and magma conditions (e.g. Odé, 1957; Grosfils and Head, 1994; Jolly and Sanderson, 1995, 1997; Hou et al., 2010; Lahiri et al., 2019). Deriving these overarching controls on dyke emplacement assumes that dykes preferentially develop orthogonal to $\sigma_{3}$ within the $\sigma_{1}-\sigma_{2}$ plane (e.g. Anderson, 1951). Although the orientation of dykes and dyke segments studied here is variable, they are broadly N- to NE-trending and subvertical $\left(\sim 80-90^{\circ}\right)$, suggesting an average syn-emplacement $\sigma_{3}$ currently oriented $100 / 00^{\circ}$ (Fig. 16). Mutually orthogonal to the calculated $\sigma_{3}$ on a lower-hemisphere equal-area stere- 
Table 2. Dyke volume estimates.

\begin{tabular}{|c|c|c|c|c|c|c|}
\hline Name & $\begin{array}{r}\text { Length } \\
(L) \\
(\mathrm{km})\end{array}$ & $\begin{array}{r}\text { Thickness } \\
(\mathrm{km})\end{array}$ & $\begin{array}{r}\text { Minimum } \\
\text { height }(H) \\
(\mathrm{km})\end{array}$ & $\begin{array}{r}\text { Maximum } \\
\text { height }(H) \\
(\mathrm{km})\end{array}$ & $\begin{array}{r}\text { Minimum } \\
\text { volume } \\
\left(\mathrm{km}^{3}\right)\end{array}$ & $\begin{array}{r}\text { Maximum } \\
\text { volume } \\
\left(\mathrm{km}^{3}\right)\end{array}$ \\
\hline A & 007.1 & 0.02 & 3.5 & 24 & 00.5 & 03.4 \\
\hline $\mathrm{B}^{*}$ & 074.1 & 0.02 & 3.5 & 24 & 05.2 & 35.6 \\
\hline $\mathrm{C}$ & 106.4 & 0.02 & 3.5 & 24 & 07.4 & 51.1 \\
\hline $\mathrm{D}$ & 084.5 & 0.02 & 3.5 & 24 & 05.9 & 40.6 \\
\hline $\mathrm{E}$ & 066.4 & 0.02 & 3.5 & 24 & 04.6 & 31.9 \\
\hline $\mathrm{F}$ & 147.0 & 0.02 & 3.5 & 24 & 10.3 & 70.6 \\
\hline $\mathrm{G}^{*}$ & 170.7 & 0.02 & 3.5 & 24 & 11.9 & 81.9 \\
\hline $\mathrm{H}^{*}$ & 157.0 & 0.02 & 3.5 & 24 & 11.0 & 75.4 \\
\hline I & 125.8 & 0.02 & 3.5 & 24 & 08.8 & 60.4 \\
\hline $\mathrm{J}$ & 035.9 & 0.02 & 3.5 & 24 & 02.5 & 17.2 \\
\hline $\mathrm{K}$ & 054.1 & 0.02 & 3.5 & 24 & 03.8 & 26.0 \\
\hline $\mathrm{L}$ & 056.4 & 0.02 & 3.5 & 24 & 03.9 & 27.1 \\
\hline M & 017.0 & 0.02 & 3.5 & 24 & 01.2 & 08.2 \\
\hline $\mathrm{N}$ & 008.6 & 0.02 & 3.5 & 24 & 00.6 & 04.1 \\
\hline $\mathrm{O}$ & 048.2 & 0.02 & 3.5 & 24 & 03.4 & 23.1 \\
\hline $\mathrm{P}$ & 021.1 & 0.02 & 3.5 & 24 & 01.5 & 10.1 \\
\hline Q & 082.7 & 0.02 & 3.5 & 24 & 05.8 & 39.7 \\
\hline $\mathrm{R}$ & 019.0 & 0.02 & 3.5 & 24 & 01.3 & 09.1 \\
\hline S & 017.9 & 0.02 & 3.5 & 24 & 01.3 & 08.6 \\
\hline $\mathrm{T}$ & 027.3 & 0.02 & 3.5 & 24 & 01.9 & 13.1 \\
\hline $\mathrm{U}$ & 042.5 & 0.02 & 3.5 & 24 & 03.0 & 20.4 \\
\hline V & 003.5 & 0.02 & 3.5 & 24 & 00.2 & 01.7 \\
\hline W & 013.1 & 0.02 & 3.5 & 24 & 00.9 & 06.3 \\
\hline$X$ & 013.5 & 0.02 & 3.5 & 24 & 00.9 & 06.5 \\
\hline $\mathrm{Y}$ & 037.7 & 0.02 & 3.5 & 24 & 02.6 & 18.1 \\
\hline $\mathrm{Z}$ & 027.6 & 0.02 & 3.5 & 24 & 01.9 & 13.2 \\
\hline
\end{tabular}

* Total values encompassing all physically unconnected segments of these dykes.

ographic projection are two axes, at $010 / 00$ and $280 / 90^{\circ}$, which can be ascribed to $\sigma_{1}$ or $\sigma_{2}$, depending on their proximity to the cluster of measured dyke poles (e.g. Jolly and Sanderson, 1997; Lahiri et al., 2019). Specifically, the angle measured along the $\sigma_{1}-\sigma_{3}$ plane between the cluster of dykes and $\sigma_{1}$ (i.e. $\theta_{2}$ ) will be greater than that measured along the $\sigma_{2}-\sigma_{3}$ plane between the data and $\sigma_{2}$ (i.e. $\theta_{1}$; Fig. 16) (e.g. Jolly and Sanderson, 1997; Lahiri et al., 2019). Our data thus suggest that during dyking the overarching stress field in the study area was extensional with a vertical $\sigma_{1}\left(000 / 90^{\circ}\right)$ and horizontal $\mathrm{N}$-trending $\sigma_{2}\left(010 / 00^{\circ}\right)$ (Fig. 16). The synemplacement, $\sim \mathrm{W}$ trending, horizontal $\sigma_{3}$ axis we define is comparable to suggested W- to NW-trending extension directions, estimated from tectonic fault orientations and seafloor spreading patterns, for Late Jurassic-to-Early Cretaceous rifting and break-up offshore NW Australia (e.g. Hopper et al., 1992; Driscoll and Karner, 1998; Heine and Müller, 2005). Where NW-trending dykes may dominate to the west of the study area (Fig. 15c) (Velayatham et al., 2018), we anticipate that the horizontal principal stress axes $\left(\sigma_{2}\right.$ and $\left.\sigma_{3}\right)$ were oriented NW-SE and NE-SW, respectively, whilst $\sigma_{1}$ remained vertical.

\subsubsection{Tectono-magmatic setting and source of the Exmouth Dyke Swarm}

Magmatism across the North Carnarvon Basin has been attributed to decompression melting during rifting (Karner and Driscoll, 1999), coupled rifting and small-scale convective partial melting (e.g. Mutter et al., 1988; Hopper et al., 1992; Mihut and Müller, 1998), and/or mantle plume activity (e.g. Mihut and Müller, 1998; Müller et al., 2002; Rohrman, 2013, 2015). We show that emplacement of the Exmouth Dyke Swarm occurred during the Late Jurassic ( 152-147 Ma), after intrusion of extensive sill complexes (e.g. Figs. 6 and 7). Individual dykes likely propagated laterally away from a source focal area, which we infer was located on the $\mathrm{Cu}$ vier Margin, SSE of the study area (Fig. 15c). Dyking and earlier sill emplacement thus predated the main phase of igneous activity recorded across the North Carnarvon Basin, which was associated with the formation of the $\sim 136-$ 130 Ma continent-ocean transition zones bordering the Gascoyne and Cuvier margins and ultimately continental breakup in the Hauterivian (e.g. Mihut and Müller, 1998; Symonds et al., 1998; Robb et al., 2005; Direen et al., 2007; Rey et al., 

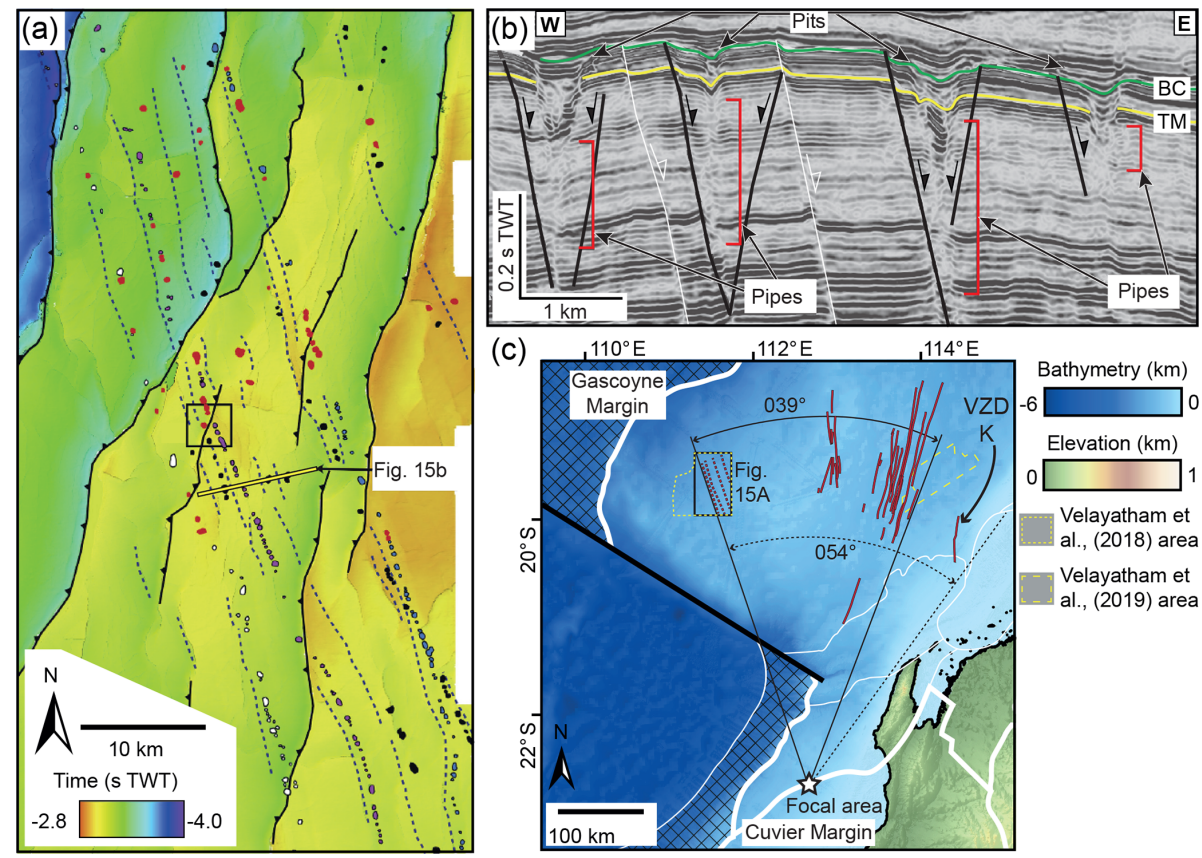

Figure 15. (a) Near Base Cretaceous unconformity time-structure map from the western sector of the Exmouth Plateau, with interpreted dyke-induced normal fault traces (dashed lines) and pit craters (circles) highlighted (modified from Velayatham et al., 2018). See (c) for location. (b) Interpreted seismic section showing the cross-section structure of possible dyke-induced normal faults and pit craters (modified from Velayatham et al., 2018). See Fig. 15a for location. (c) Map of dykes interpreted in this study and those perhaps marked by possible dyke-induced faults and pit craters in the western sector of the Exmouth Plateau (see also Velayatham et al., 2018). The interpreted dykes broadly define a radiating swarm, across at least a $39^{\circ}$ arc, centred on a focal area on the Carnarvon Terrace on the Cuvier Margin. We note the orientation of VZD K fits poorly with the radiating geometry of the rest of the dyke swarm, but if it is part of the Exmouth Dyke Swarm we suggest that the swarm could extend across a $\sim 54^{\circ}$ arc.

2008; Reeve et al., 2019). Seismic reflection data also reveal that there was little upper crustal normal faulting or rifting across the Exmouth Plateau in the Late Jurassic $(\beta \sim 1-1.1$; where $\beta$ is the stretching factor), immediately prior to and during dyking (e.g. Driscoll and Karner, 1998; Karner and Driscoll, 1999; Bilal et al., 2018). These age relationships suggest that the Exmouth Dyke Swarm and earlier sills were likely not associated with rift-related melting, which appears to have initiated in the Early Cretaceous (cf. Mutter et al., 1988; Hopper et al., 1992; Mihut and Müller, 1998; Karner and Driscoll, 1999). Instead, the large extent and radial disposition of the Exmouth Dyke Swarm suggests it may have been sourced from either a regional, thermal mantle anomaly (e.g. a plume or small-scale convection cell) or a large volcanic system (e.g. Odé, 1957; Speight et al., 1982; Ernst et al., 1995; Ernst and Buchan, 1997).

Any process invoked to explain the origin of a thermal anomaly in the mantle in the Late Jurassic, and potentially into the Early Cretaceous, needs to account for (i) the Late Jurassic distribution of magmatism across the Gascoyne and Cuvier margins (e.g. Mutter et al., 1988; Hopper et al., 1992; Mihut and Müller, 1998; Müller et al., 2002; Rohrman, 2013) and (ii) recognition of circumferential denudation patterns and formation of contemporaneous regional unconfor- mities (e.g. the near Base Cretaceous unconformity) (Underhill and Partington, 1993; Rohrman, 2015). Two possible mantle plume sites on the Cuvier Margin have previously been proposed, with one located on the Bernier Platform, initiating at $\sim 136 \mathrm{Ma}$, and the other active on the conjugate to the Cuvier Margin near the current Cape Range Fracture Zone between $\sim 165$ and $136 \mathrm{Ma}$ (e.g. Fig. 17a) (cf. Mihut and Müller, 1998; Müller et al., 2002; Rohrman, 2015). Mantle plume activity has previously been discounted as a viable source for Late Jurassic-to-Early Cretaceous magmatism, because no clear hotspot tracks have been identified (e.g. Müller et al., 2002), although Rohrman (2015) argued that the Quokka Rise and Zenith Plateau are part of such a track (Fig. 17a). An alternative interpretation to a mantle plume source is that melting reflects small-scale mantle convection instigated by juxtaposition of thick and thin lithosphere across a transform margin (e.g. the Cape Range Fracture Zone) (e.g. Mutter et al., 1988; Müller et al., 2002). Because the formation of transform margins along the NW Australian Shelf occurred during break-up of Greater India and Australia in the Early Cretaceous $(\sim 136-130 \mathrm{Ma})$, coincident with the age of the proposed Bernier Platform mantle plume, it seems unlikely that these processes could have generated the Late Jurassic Exmouth Dyke Swarm (cf. Mihut 


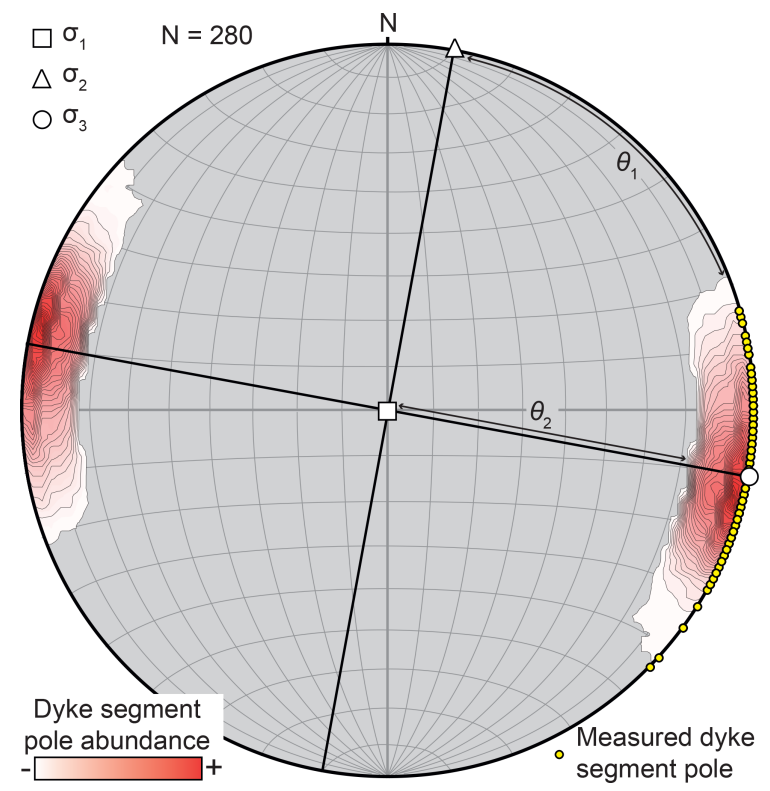

Figure 16. Equal-area lower-hemisphere stereographic projection of poles (yellow filled circles) to all measured VZD (dyke) segments. Dyke pole data are contoured assuming a measured dip error of $10^{\circ}$; data was plotted in Stereonet 10.0 and contoured using the Kamb contouring method with an interval of 1 and a significance level of 5 . The minimum principal stress axis $\left(\sigma_{3}\right)$ was defined as the centre of the dyke pole cluster, with the geometry of the cluster used to distinguish which of the two orthogonal axes were $\sigma_{1}$ and $\sigma_{2}$ (Jolly and Sanderson, 1997).

and Müller, 1998; Müller et al., 2002). The interpreted age and distribution of the Exmouth Dyke Swarm thus fits best with the mantle plume model proposed by Rohrman (2015).

Within the framework of the mantle plume model proposed by Rohrman (2015), melting is expected to have initiated $\sim 165 \mathrm{Myr}$ ago, leading to emplacement of a maficto-ultramafic high-velocity magmatic body near the Moho and formation of the Callovian unconformity during associated uplift (i.e. vertical $\sigma_{1}$; Fig. 18a). This high-velocity magmatic body likely fed the Late Jurassic sill complex prior to emplacement of the Exmouth Dyke Swarm (Fig. 18a) (e.g. Symonds et al., 1998; Magee et al., 2013a, 2017; Rohrman, 2013). We suggest that emplacement of this sill complex occurred as plume activity waned and uplift ceased, causing the regional stress to relax such that the vertical principal stress axis became $\sigma_{3}$ and basin subsidence initiated (Fig. 18b); this change in stress orientation could explain why the ascent of buoyant magma from the high velocity body formed a sill complex rather than a vertical dyke swarm. Layering in the sedimentary basins may also have favoured sill emplacement (Fig. 18b) (see Magee et al., 2016b, and references therein). The apparent transition from sill-complex formation to intrusion of the Exmouth Dyke Swarm in the Late Jurassic marks an abrupt change in emplacement conditions. To generate the Exmouth Dyke Swarm, which broadly co-
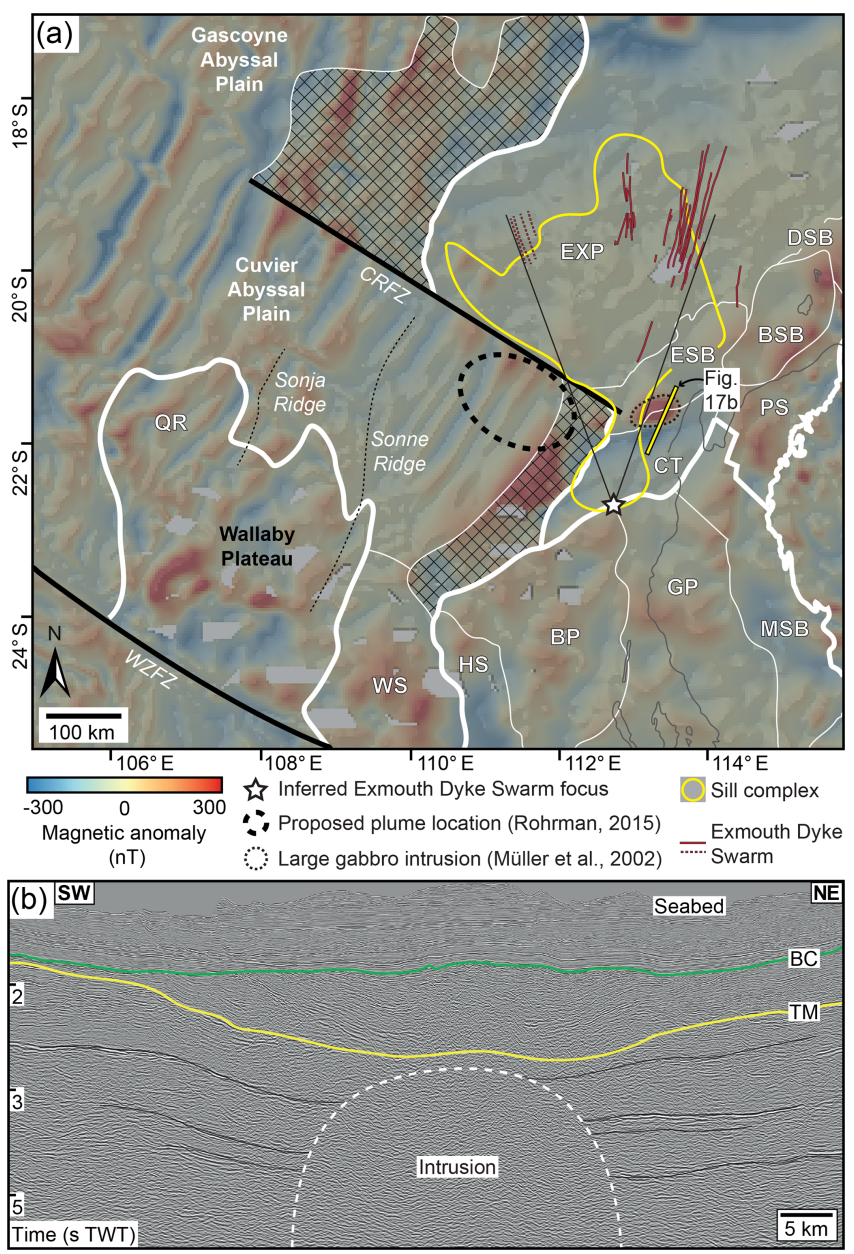

Figure 17. (a) Tectono-magmatic elements of the north and south Carnarvon Basins, including the inferred extent of the Exmouth Dyke Swarm and its focal area, overlain on a map of total magnetic intensity grid (EMAG2v2). Also highlighted are a proposed plume conduit site (Rohrman, 2015) and location of a large, mafic intrusion (Müller et al., 2002). Tectonic elements highlighted include EXP = Exmouth Plateau; $\mathrm{DSB}=$ Dampier Sub-basin; $\mathrm{BSB}=$ Barrow Sub-basin; $\mathrm{ESB}=$ Exmouth Subbasin; $\mathrm{CT}=$ Carnarvon Terrace; $\mathrm{MSB}=$ Merlinleigh Sub-basin; $\mathrm{PS}=$ Peedamullah Shelf; $\mathrm{GP}=$ Gascoyne Platform; $\mathrm{BP}=$ Bernier Platform; HS = Houtman Sub-basin; WS = Wallaby Saddle; $\mathrm{QR}=$ Quokka Rise; CRFZ = Cape Range Fracture Zone; and the $\mathrm{WZFZ}=$ Wallaby-Zenith Fracture Zone. (b) Interpreted seismic section across the large mafic intrusion highlighted in (a).

incided with a phase of uplift and denudation (i.e. formation of the Base Cretaceous unconformity), we show $\sigma_{1}$ had become vertical, and $\sigma_{3}$ was circumferential to the swarms focal area (Figs. 16a, 18c, and d). We suggest that these conditions, which favoured dyking rather than sill-complex emplacement, could have been instigated by a renewed influx of plume material, with the swarm fed either (i) directly from a thermal mantle anomaly (Fig. 18c) or (ii) via a large intrusive centre located at the southern boundary of 

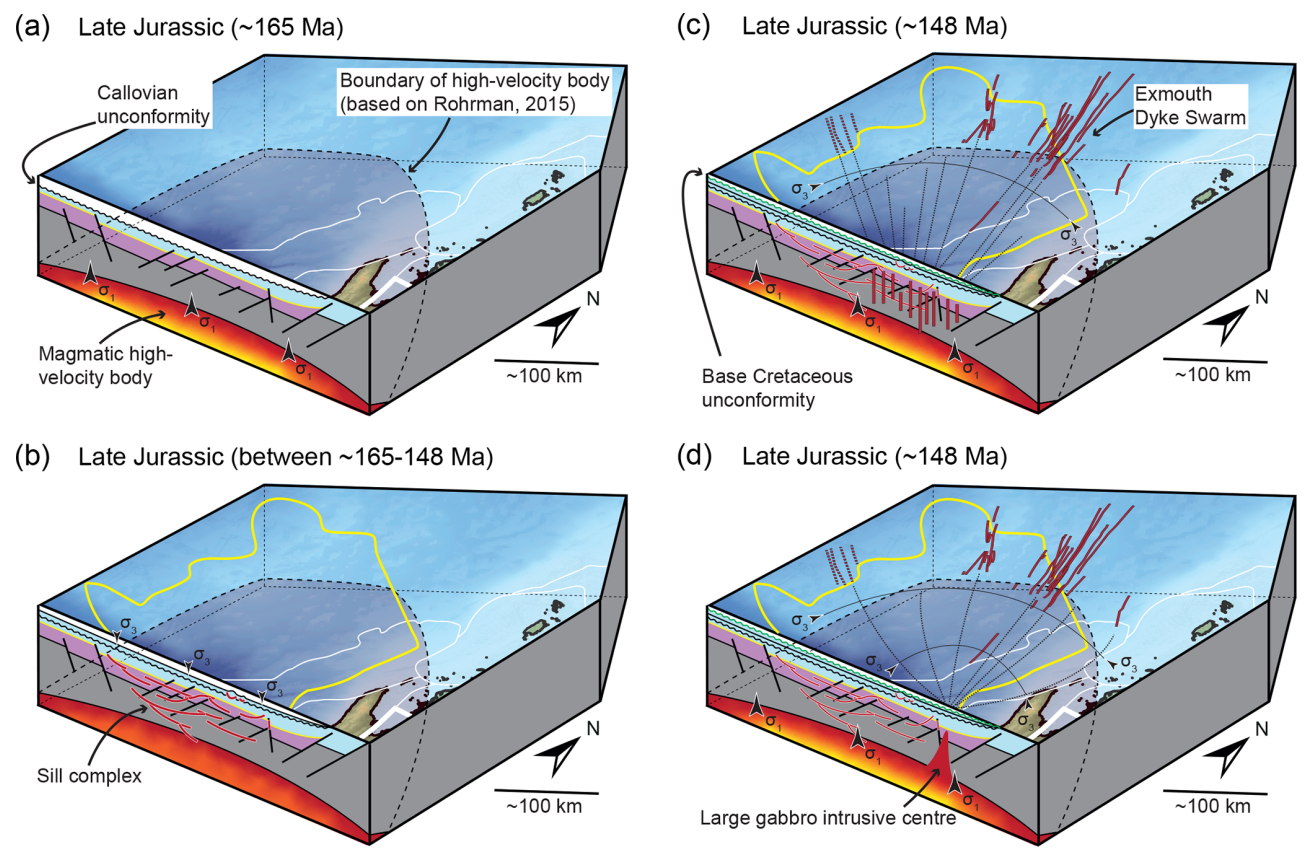

Figure 18. Schematics depicting the magmatic evolution of the study area during the Late Jurassic. (a) Initial igneous activity led to development of a high-velocity body at the base of the crust and synchronous uplift (i.e. horizontal $\sigma_{3}$ ) and erosion to form the Callovian unconformity. (b) As emplacement of the high-velocity body waned, uplift transitioned to subsidence, marked by a rotation to a vertical $\sigma_{3}$ and intrusion of sill complexes. (c-d) A renewed phase of magmatism and uplift rotated $\sigma_{3}$ to a horizontal orientation that favoured formation of the Exmouth Dyke Swarm. The Exmouth dyke swarm may have been fed directly from a mantle plume (c) or a large volcanic centre (d).

the Exmouth Sub-basin, which manifests as a sub-circular ( $\sim 20 \mathrm{~km}$ diameter), positive magnetic anomaly and a zone of disturbance in seismic reflection data (e.g. Figs. 17a and 18d) (Müller et al., 2002). Late Jurassic crustal extension by dyking during the Late Jurassic, which we estimate could be up to $\sim 0.33 \%$, was likely much less than that accommodated by Tithonian-to-Valanginian faulting in the lower crust ( $\beta \sim 2.65-2.8)$ and upper crust $(\beta \sim 1-1.1)$ across the Exmouth Plateau (cf. Karner and Driscoll, 1999; Rohrman, 2015). Cessation of plume activity immediately after dyking, following removal or reduction of the thermal anomaly, may explain the rapid subsidence (i.e. $<0.24 \mathrm{~mm} \mathrm{yr}^{-1}$ ) required to accommodate the Late Jurassic-to-Early Cretaceous Barrow Group (cf. Reeve et al., 2016). Overall, our data seemingly support the presence of a mantle plume offshore NW Australia during the Late Jurassic to Early Cretaceous (e.g. Müller et al., 2002; Rohrman, 2013, 2015). However, it remains uncertain whether igneous activity coincident with Hauterivian break-up was also related to the presence of a mantle plume or not.

\subsection{Implications and future studies}

Giant dyke swarms are recognised worldwide onshore (e.g. Halls, 1982; Halls and Fahrig, 1987; Ernst and Baragar, 1992; Coffin and Eldholm, 1994; Coffin and Eldholm, 2005; Bryan and Ernst, 2008; Bryan et al., 2010; Hou et al., 2010;
Ernst, 2014; Ernst and Youbi, 2017). Projection of these onshore dyke swarms and the known importance of dyking for break-up and formation of magma-rich margins suggests dyke swarms should also be prevalent on offshore continental shelves (see Magee et al., 2019, and references therein). Our work extends a growing consensus that vertical dykes can be recognised in seismic reflection data imaging continental margins (e.g. Jaunich, 1983; Kirton and Donato, 1985; Wall et al., 2010; Bosworth et al., 2015; Ardakani et al., 2017; Holford et al., 2017; Malehmir et al., 2018; Plazibat et al., 2019). Key criteria for defining vertical dykes in seismic reflection data include (i) identification of thin, long, tall, typically sub-vertical zones of disturbance within otherwise subparallel reflections defining the host rock (e.g. Figs. 6 and 7) (e.g. Wall et al., 2010; Eide et al., 2018; Minakov et al., 2018); (ii) lack of lateral or vertical offset of host rock strata, best revealed by mapping piercing points (e.g. fluvial channels, pre-existing structures) across inferred dyke-like features (e.g. Figs. 5 and 8), which suggests that the features are not strike-slip or steeply dipping normal faults; and (iii) potential association with overlying pit craters or dyke-induced normal faults, which are likely easier to resolve and map in seismic reflection data compared to dykes (e.g. Figs. 6, 7, 12 and 13). By increasing our collective awareness of how these criteria can be used to identify dykes in seismic reflection data, we expect that more dyke swarms will be revealed across continental margins worldwide. Recognition of dyke 
swarms within seismic reflection data will help us produce better physical models of the subsurface, aiding our understanding of a margins thermal history, and fluid and/or gas plumbing systems of sedimentary basins.

We also demonstrate that mapping dykes, dyke-induced normal faults, and pit craters across vast areas using seismic reflection data provides unprecedented opportunities to resolve and quantify their natural structure in 3D (e.g. Figs. 413). Future work should focus on (i) unravelling the geophysical expression of dykes, such that additional and more accurate quantitative data (e.g. dyke thickness) can be recovered; (ii) deciphering the kinematic history of dyke-induced normal faults, which we may expect should relate to and thus inform dyke structure and emplacement dynamics; (iii) quantifying the geometrical relationship between pit craters and the dyke intrusions driving their formation; and (iv) determining whether dyke-induced normal faults and pit craters can be used to constrain the temporal evolution of a dyke swarm. These four initiatives will provide new insights into and allow us to test hypotheses concerning the 3D structure and growth of dyke swarms and their associated structures. We envisage that these findings will improve how we can invert the surface expression of active or ancient dyke swarms, i.e. dyke-induced normal faults and pit craters exposed at the surface of Earth or other planetary bodies, to recover more information on their otherwise inaccessible subsurface structure and the processes that formed them.

\section{Conclusions}

Dyke swarms are ubiquitous on Earth and other planetary bodies. Yet we know little of the 3D structure of dyke swarms, because the pseudo-2D nature of planetary surfaces means that we can typically only access their plan-view morphology, and then only at the given erosion level. Here we use a suite of seismic reflection datasets from the Exmouth Plateau, offshore NW Australia, to map 26 Late Jurassic $(\sim 152-147 \mathrm{Ma})$ dykes in 3D across $\sim 40000 \mathrm{~km}^{2}$; we name this the Exmouth Dyke Swarm. The mapped dykes correspond to $\sim \mathrm{N}$ - to NE-trending vertical zones of disturbance within the seismic reflection data that can be up to $171 \mathrm{~km}$ long, $355 \mathrm{~m}$ wide, likely $9 \mathrm{~km}$ high, and sub-divided into smaller segments with subtly different orientations. Directly above the dykes are a series of graben-bounding normal fault systems, which dip towards and converge upper dyke tips, and sub-vertical pipe-like features; we interpret these structures as dyke-induced normal faults and pit craters. Our quantitative analyses reveal dyke length broadly follows a power-law distribution consistent with previous studies, whilst dyke spacing conforms to a negative-exponential distribution, which we attribute to sampling of different dyke generations. Across the study area, dyke orientations are consistent with an ENE-trending horizontal and vertical minimum and maximum principal stress axes, respectively. How- ever, recognition of possible dyke-induced normal faults and pit craters elsewhere on the Exmouth Plateau suggests that dykes are distributed radially across a $39^{\circ}$ arc, implying the minimum principal stress axis was circumferential, centred on the Cuvier Margin to the south. This focal area on the Cuvier Margin likely marks the dyke swarm source, which is consistent with evidence that the dykes propagated laterally northwards. Overall, we suggest emplacement of the Exmouth Dyke Swarm related to renewed activity of a mantle plume located on the Cuvier Margin between $\sim 165$ and $136 \mathrm{Ma}$. Our work demonstrates that seismic reflection data can be used to identify vertical dykes across vast areas on continental margins, whilst providing unprecedented data on the 3D structure of these natural systems. By defining a series of criteria that can be used to interpret dykes in seismic reflection data, we anticipate future studies will (i) recognise dyke swarms across continental margins worldwide, providing new insights into basin evolution (e.g. thermal histories) and controls on fluid flow; (ii) provide more robust constraints on dyke swarm geometry, allowing previous models and hypotheses of their 3D structure to be tested; (iii) reveal how dyke-induced normal faults and pit craters are kinematically linked to dyking; and (iv) demonstrate how dyke swarms may be expressed at the syn-emplacement surface, meaning we can improve inversions of such surficial features observed on Earth and other planetary bodies to better predict underlying dyke structures.

Data availability. The seismic reflection and well data used (see text for details) are publicly available through Geoscience Australia at http://www.ga.gov.au/nopims, last access: 25 January 2020. All measurements presented are within, or based on data within, the compiled tables and the Supplement tables.

Supplement. The supplement related to this article is available online at: https://doi.org/10.5194/se-11-579-2020-supplement.

Author contributions. CM designed and conducted the research, interpreted the data, and prepared the article. CALJ contributed to data interpretation and article editing.

Competing interests. The authors declare that they have no conflict of interest.

Acknowledgements. We are grateful to Geoscience Australia for making all data used in this study publicly available. Schlumberger are thanked for provision of Petrel seismic interpretation software. We are extremely thankful to Janine Kavanagh and Jonathon Hardman for their time and effort in putting together constructive reviews, and to the editorial team for their help with the peer-review process. 
Financial support. This research has been supported by the NERC (grant no. NE/R014086/1).

Review statement. This paper was edited by Federico Rossetti and reviewed by Janine Kavanagh and Jonathon Hardman.

\section{References}

Anderson, E. M.: The dynamics of faulting and dyke formation with applications to Britain, Hafner Pub. Co., Edinburgh, 206 pp., 1951.

Ardakani, E. P., Schmitt, D. R., and Currie, C. A.: Geophysical evidence for an igneous dike swarm, Buffalo Creek, Northeast Alberta, Geol. Soc. Am. Bull., 130, 1059-1072, 2017.

Baragar, W., Ernst, R., Hulbert, L., and Peterson, T.: Longitudinal petrochemical variation in the Mackenzie dyke swarm, northwestern Canadian Shield, J. Petrol., 37, 317-359, 1996.

Bilal, A., McClay, K., and Scarselli, N.: Fault-scarp degradation in the central Exmouth Plateau, North West Shelf, Australia, Geol. Soc. Lond. Spec. Publ., 476, SP476.411, 27 pp., 2018.

Black, M., McCormack, K., Elders, C., and Robertson, D.: Extensional fault evolution within the Exmouth Sub-basin, North West Shelf, Australia, Mar. Petrol. Geol., 85, 301-315, 2017.

Bleeker, W. and Ernst, R.: Short-lived mantle generated magmatic events and their dyke swarms: the key unlocking Earth's paleogeographic record back to $2.6 \mathrm{Ga}$, Dyke swarms - time markers of crustal evolution, in: Dyke Swams-Time Markers of Crustal Evolution, edited by: Hanski, E., Mertanen, S., Rämö, T., and Vuollo, J., Taylor and Francis/Balkema, London, 3-26, 2006.

Bosworth, W., Stockli, D. F., and Helgeson, D. E.: Integrated outcrop, 3D seismic, and geochronologic interpretation of Red Sea dike-related deformation in the Western Desert, Egypt-The role of the 23 Ma Cairo "mini-plume", J. Afr. Earth Sci., 109, 107$119,2015$.

Brown, A. R.: Interpretation of three-dimensional seismic data, 6th Edn., AAPG Memoir 42, SEG Investigations in Geophysics No. 9, AAPG and SEG, Oklahoma, USA, 534 pp., 2011.

Bryan, S. E. and Ernst, R. E.: Revised definition of large igneous provinces (LIPs), Earth-Sci. Rev.s, 86, 175-202, 2008.

Bryan, S. E., Peate, I. U., Peate, D. W., Self, S., Jerram, D. A., Mawby, M. R., Marsh, J. G., and Miller, J. A.: The largest volcanic eruptions on Earth, Earth-Sci. Rev., 102, 207-229, 2010.

Buchan, K. and Ernst, R.: Diabase dyke swarms of Nunavut, Northwest Territories and Yukon, Canada, Geological Survey of Canada, Open File, 7464, 293149, https://doi.org/10.4095/293149, 2013.

Buchan, K. L. and Ernst, R. E.: Giant circumferential dyke swarms: catalogue and characteristics, in: Dyke Swarms of the World: A Modern Perspective, edited by: Srivastava, R., Ernst, R., and Peng, P., Springer, Singapore, 44 pp., 2018 a.

Buchan, K. L. and Ernst, R. E.: A giant circumferential dyke swarm associated with the High Arctic Large Igneous Province (HALIP), Gondwana Res., 58, 39-57, 2018b.

Bunger, A. P., Menand, T., Cruden, A., Zhang, X., and Halls, H.: Analytical predictions for a natural spacing within dyke swarms, Earth Planet. Sci. Lett., 375, 270-279, 2013.
Cartwright, J. and Santamarina, C.: Seismic characteristics of fluid escape pipes in sedimentary basins: implications for pipe genesis, Mar. Petrol. Geol., 65, 126-140, 2015.

Childs, K., Banfield, J., Jakymec, M., and Jones, A.: Well Completion Report: Chester-1 \& Chester-1 ST1 interpretative data, Hess, National Offshore Petroleum Information Management System, Geosci. Austr., 1-353, 2013.

Cladouhos, T. T. and Marrett, R.: Are fault growth and linkage models consistent with power-law distributions of fault lengths?, J. Struct. Geol., 18, 281-293, 1996.

Coffin, M. F. and Eldholm, O.: Large igneous provinces: crustal structure, dimensions, and external consequences, Rev. Geophys., 32, 1-36, 1994.

Coffin, M. F. and Eldholm, O.: Large igneous provinces, in: Encyclopedia of Geology, edited by: Selley, R. C., Cocks, R., and Plimer, I. R., Elsevier, Oxford Encycl. Geol., 315-323, 2005.

Direen, N. G., Borissova, I., Stagg, H., Colwell, J. B., and Symonds, P. A.: Nature of the continent-ocean transition zone along the southern Australian continental margin: a comparison of the Naturaliste Plateau, SW Australia, and the central Great Australian Bight sectors, Geol. Soc. Lond. Spec. Publ., 282, 239-263, 2007.

Direen, N. G., Stagg, H. M. J., Symonds, P. A., and Colwell, J. B.: Architecture of volcanic rifted margins: new insights from the Exmouth - Gascoyne margin, Western Australia, Austr. J. Earth Sci., 55, 341-363, 2008.

Driscoll, N. W. and Karner, G. D.: Lower crustal extension across the Northern Carnarvon basin, Australia: Evidence for an eastward dipping detachment, J. Geophys. Res.-Sol. Ea., 103, 49754991, 1998.

Ebinger, C. J. and Casey, M.: Continental breakup in magmatic provinces: An Ethiopian example, Geology, 29, 527-531, 2001.

Eide, C. H., Schofield, N., Lecomte, I., Buckley, S. J., and Howell, J. A.: Seismic Interpretation of Sill-complexes in Sedimentary Basins: The "sub-sill Imaging Problem", J. Geol. Soc., 175, 193 209, 2018.

Ernst, R., Head, J., Parfitt, E., Grosfils, E., and Wilson, L.: Giant radiating dyke swarms on Earth and Venus, Earth-Sci. Rev., 39, 1-58, 1995.

Ernst, R., Grosfils, E., and Mege, D.: Giant dike swarms: Earth, venus, and mars, Annu. Rev. Earth Pl. Sc., 29, 489-534, 2001.

Ernst, R. E.: Large igneous provinces, Cambridge University Press, 653 pp., 2014.

Ernst, R. E. and Baragar, W. R. A.: Evidence from magnetic fabric for the flow pattern of magma in the Mackenzie giant radiating dyke swarm, Nature, 356, 511-513, 1992.

Ernst, R. E. and Buchan, K. L.: Giant radiating dyke swarms: their use in identifying pre-Mesozoic large igneous provinces and mantle plumes, Large igneous provinces: continental, Geophys. Monogr., 100, 297-333, 1997.

Ernst, R. E. and Jowitt, S. M.: Large igneous provinces (LIPs) and metallogeny, Tectonics, Metallogeny, and Discovery: the North American Cordillera and Similar Accretionary Settings, edited by: Colpron, M., Bissig, T., Rusk, B. G., and Thompson, J. F. H., Soc. Econ. Geol. Spec. Publ., 17, 17-51, 2013.

Ernst, R. E. and Youbi, N.: How Large Igneous Provinces affect global climate, sometimes cause mass extinctions, and represent natural markers in the geological record, Palaeogeogr. Palaeocl., 478, 30-52, 2017. 
Ernst, R. E., Bleeker, W., Soderlund, U., and Kerr, A. C.: Large Igneous Provinces and supercontinents: Toward completing the plate tectonic revolution, Lithos, 174, 1-14, 2013.

Frey, Ø., Planke, S., Symonds, P. A., and Heeremans, M.: Deep crustal structure and rheology of the Gascoyne volcanic margin, western Australia, Mar. Geophys. Res., 20, 293-311, 1998.

Gartrell, A., Torres, J., Dixon, M., and Keep, M.: Mesozoic rift onset and its impact on the sequence stratigraphic architecture of the Northern Carnarvon Basin, APPEA J., 56, 143-158, 2016.

Grosfils, E. B. and Head, J. W.: The global distribution of giant radiating dike swarms on Venus: Implications for the global stress state, Geophys. Res. Lett., 21, 701-704, 1994.

Gudmundsson, A.: Form and dimensions of dykes in eastern Iceland, Tectonophysics, 95, 295-307, 1983.

Gudmundsson, A.: Geometry, formation and development of tectonic fractures on the Reykjanes Peninsula, southwest Iceland, Tectonophysics, 139, 295-308, 1987.

Halls, H.: The importance and potential of mafic dyke swarms in studies of geodynamic processes, Geosci. Can., 9, 145-154, 1982.

Halls, H. C. and Fahrig, W. F.: Mafic Dyke Swarms: A Collection of Papers Based on the Proceedings of an International Conference Held at Erindale College, University of Toronto, Ontario, Canada, 4 to 7 June 1985, 34, St. John's, Nfld., Geological Association of Canada, 1987.

Harding, T., Vierbuchen, R., and Christie-Blick, N.: Structural styles, plate-tectonic settings, and hydrocarbon traps of divergent (transtensional) wrench faults, in: Strike-slip deformation, basin formation and sedimentation, Soc. Econ. Pa., 37, 51-77, 1985.

Harding, T. P.: Seismic characteristics and identification of negative flower structures, positive flower structures, and positive structural inversion, AAPG Bull., 69, 582-600, 1985.

Hardy, S.: Does shallow dike intrusion and widening remain a possible mechanism for graben formation on Mars?, Geology, 44, 107-110, 2016.

Healy, D., Rizzo, R., Duffy, M., Farrell, N. J., Hole, M. J., and Muirhead, D.: Field evidence for the lateral emplacement of igneous dykes: Implications for 3D mechanical models and the plumbing beneath fissure eruptions, Volcanica, 1, 85-105, 2018.

Heine, C. and Müller, R.: Late Jurassic rifting along the Australian North West Shelf: margin geometry and spreading ridge configuration, Aust. J. Earth Sci., 52, 27-39, 2005.

Hocking, R.: Jurassic deposition in the southern and central North West Shelf, Western Australia: Geological Survey Western Australia Record, 199217, 101 pp., 1992.

Hocking, R. M., Moors, H. T., and Van de Graaff, W. E.: Geology of the carnarvon basin, Western Australia, State Print. Division, 289 pp., 1987.

Holford, S. P., Schofield, N., Jackson, C. A. L., Magee, C., Green, P. F., and Duddy, I. R.: Impacts of igneous intrusions on source and reservoir potential in prospective sedimentary basins along the western Australian continental margin, in: The Sedimentary Basins of Western Australia IV, edited by: Keep, M. and Moss, S. J., Proceedings of the Petroleum Exploration Society of Australia Symposium, Perth, WA, 2013.

Holford, S. P., Schofield, N., and Reynolds, P.: Subsurface fluid flow focused by buried volcanoes in sedimentary basins: Evidence from 3D seismic data, Bass Basin, offshore southeastern Australia, Interpretation, 5, SK39-SK50, 2017.
Hopper, J. R., Mutter, J. C., Larson, R. L., and Mutter, C. Z.: Magmatism and rift margin evolution: Evidence from northwest Australia, Geology, 20, 853-857, 1992.

Hou, G., Kusky, T., Wang, C., and Wang, Y.: Mechanics of the giant radiating Mackenzie dyke swarm: a paleostress field modeling, J. Geophys. Res.-Sol. Ea., 115, B02402, https://doi.org/10.1029/2007JB005475, 2010.

Jamtveit, B., Svensen, H., Podladchikov, Y. Y., and Planke, S.: Hydrothermal vent complexes associated with sill intrusions in sedimentary basins, Geol. Soc. Spec. Publ., 234, 233-241, 2004.

Jaunich, S.: Tertiary intrusions on the south-western African margin, in: Seismic Expression of Structural Styles. Studies in Geology Series, edited by: Bally, A. W., 1, AAPG, Tulsa, 10-14, 1983.

Jitmahantakul, S. and McClay, K.: Late Triassic - Mid-Jurassic to Neogene extensional fault systems in the Exmouth Sub-basin, Northern Carnarvon Basin, North West Shelf, Western Australia, in: The Sedimentary Basins of Western Australia IV: Proceedings of the Petroleum Exploration Society of Australia Symposium, edited by: Keep, M. and Moss, S. J., Perth, WA, 2013.

Jolly, R. and Sanderson, D. J.: Variation in the form and distribution of dykes in the Mull swarm, Scotland, J. Struct. Geol., 17, 1543$1557,1995$.

Jolly, R. and Sanderson, D.: A Mohr circle construction for the opening of a pre-existing fracture, J. Struct. Geol., 19, 887-892, 1997.

Jowitt, S. M., Williamson, M.-C., and Ernst, R. E.: Geochemistry of the 130 to $80 \mathrm{Ma}$ Canadian High Arctic large igneous province (HALIP) event and implications for $\mathrm{Ni}-\mathrm{Cu}$-PGE prospectivity, Econ. Geol., 109, 281-307, 2014.

Ju, W., Hou, G., and Hari, K.: Mechanics of mafic dyke swarms in the Deccan Large Igneous Province: Palaeostress field modelling, J. Geodynam., 66, 79-91, 2013.

Kaiko, A. and Tait, A.: Post-rift tectonic subsidence and palaeowater depths in the northern Carnarvon Basin, Western Australia, APPEA J., 41, 367-379, 2001.

Karner, G. D. and Driscoll, N. W.: Style, timing and distribution of tectonic deformation across the Exmouth Plateau, northwest Australia, determined from stratal architecture and quantitative basin modelling, in: Continental Tectonics, Geological Society, London, Special Publications, edited by: MacNiocall, C. and Ryan, P., Geol. Soc. Lond., 164, 271-311, 1999.

Kavanagh, J. and Sparks, R. S. J.: Insights of dyke emplacement mechanics from detailed 3D dyke thickness datasets, J. Geol. Soc., 168, 965-978, 2011.

Keir, D., Pagli, C., Bastow, I. D., and Ayele, A.: The magmaassisted removal of Arabia in Afar: Evidence from dike injection in the Ethiopian rift captured using InSAR and seismicity, Tectonics, 30, TC2008, https://doi.org/10.1029/2010TC002785, 2011.

Kirton, S. and Donato, J.: Some buried Tertiary dykes of Britain and surrounding waters deduced by magnetic modelling and seismic reflection methods, J. Geol. Soc., 142, 1047-1057, 1985.

Klausen, M.: Similar dyke thickness variation across three volcanic rifts in the North Atlantic region: Implications for intrusion mechanisms, Lithos, 92, 137-153, 2006.

Klausen, M. B.: Geometry and mode of emplacement of the Thverartindur cone sheet swarm, SE Iceland, J. Volcanol. Geoth. Res., 138, 185-204, 2004. 
Krumbholz, M., Hieronymus, C. F., Burchardt, S., Troll, V. R., Tanner, D. C., and Friese, N.: Weibull-distributed dyke thickness reflects probabilistic character of host-rock strength, Nat. Commun., 5, 3272, https://doi.org/10.1038/ncomms4272, 2014.

Lahiri, S., Bhatt, S., and Mamtani, M. A.: The relation between differential stress, driving pressure ratio, tensile strength and reservoir failure in a magmatic system-Towards eruption forecasting, J. Struct. Geol., 124, 23-34, 2019.

Lemiszki, P. J. and Brown, L.: Variable crustal structure of strikeslip fault zones as observed on deep seismic reflection profiles, Geol. Soc. Am. Bull., 100, 665-676, 1988.

Longley, I., Buessenschuett, C., Clydsdale, L., Cubitt, C., Davis, R., Johnson, M., Marshall, N., Murray, A., Somerville, R., and Spry, T.: The North West Shelf of Australia - a Woodside perspective, The sedimentary basins of Western Australia, 3, 27-88, 2002.

Macdonald, R., Wilson, L., Thorpe, R., and Martin, A.: Emplacement of the Cleveland dyke: evidence from geochemistry, mineralogy, and physical modelling, J. Petrol., 29, 559-583, 1988.

Magee, C., Briggs, F., and Jackson, C. A.-L.: Lithological controls on igneous intrusion-induced ground deformation, J. Geol. Soc., 170, 853-856, 2013a.

Magee, C., Jackson, C. A.-L., and Schofield, N.: The influence of normal fault geometry on igneous sill emplacement and morphology, Geology, 41, 407-410, 2013b.

Magee, C., Duffy, O. B., Purnell, K., Bell, R. E., Jackson, C. A. L., and Reeve, M. T.: Fault-controlled fluid flow inferred from hydrothermal vents imaged in 3D seismic reflection data, offshore NW Australia, Basin Res., 28, 299-318, 2016a.

Magee, C., Muirhead, J. D., Karvelas, A., Holford, S. P., Jackson, C. A., Bastow, I. D., Schofield, N., Stevenson, C. T., McLean, C., and McCarthy, W.: Lateral magma flow in mafic sill complexes, Geosphere, 12, 809-841, 01251, 2016 b.

Magee, C., Jackson, C. A.-L., Hardman, J. P., and Reeve, M. T.: Decoding sill emplacement and forced fold growth in the Exmouth Sub-basin, offshore northwest Australia: Implications for hydrocarbon exploration, Interpretation, 5, SK11-SK22, 2017.

Magee, C., Stevenson, C. T., Ebmeier, S. K., Keir, D., Hammond, J. O., Gottsmann, J. H., Whaler, K. A., Schofield, N., Jackson, C. A., and Petronis, M. S.: Magma plumbing systems: a geophysical perspective, J. Petrol., 59, 1217-1251, 2018.

Magee, C., Ernst, R. E., Muirhead, J., Phillips, T., and Jackson, C. A.-L.: Magma Transport Pathways in Large Igneous Provinces: Lessons from Combining Field Observations and Seismic Reflection Data, in: Dyke Swarms of the World: A Modern Perspective, edited by: Srivastava, R., Ernst, R., and Peng, P., Springer, 45-85, 2019.

Malehmir, A., Bergman, B., Andersson, B., Sturk, R., and Johansson, M.: Seismic imaging of dyke swarms within the SorgenfreiTornquist Zone (Sweden) and implications for thermal energy storage, Solid Earth, 9, 1469-1485, https://doi.org/10.5194/se-91469-2018, 2018.

Marinoni, L. B.: Crustal extension from exposed sheet intrusions: review and method proposal, J. Volcanol. Geoth. Res., 107, 2746, 2001.

Mège, D. and Korme, T.: Fissure eruption of flood basalts from statistical analysis of dyke fracture length, J. Volcanol. Geoth. Res., 131, 77-92, 2004.
Mège, D., Cook, A. C., Garel, E., Lagabrielle, Y., and Cormier, M. H.: Volcanic rifting at Martian grabens, J. Geophys. Res.-Planet., 108, 5044, https://doi.org/10.1029/2002JE001852, 2003.

Mihut, D. and Müller, R. D.: Volcanic margin formation and Mesozoic rift propagators in the Cuvier Abyssal Plain off Western Australia, J. Geophys. Res., 103, 27135-27127, 1998.

Minakov, A., Yarushina, V., Faleide, J. I., Krupnova, N., Sakoulina, T., Dergunov, N., and Glebovsky, V.: Dyke emplacement and crustal structure within a continental large igneous province, northern Barents Sea, in: Circum-Arctic Lithosphere Evolution, edited by: Pease, V. and Coakley, B., 1, Geol. Soc. Lond. Spec. Publ., 460, 371-395, 2018.

Moss, J. and Cartwright, J.: 3D seismic expression of km-scale fluid escape pipes from offshore Namibia, Basin Res., 22, 481-501, 2010.

Müller, R., Mihut, D., Heine, C., O’Neill, C., and Russell, I.: Tectonic and volcanic history of the Carnarvon Terrace: Constraints from seismic interpretation and geodynamic modelling, The Sedimentary Basins of Western Australia, 3, 719-740, 2002.

Mutter, J. C. and Larson, R. L.: Extension of the Exmouth Plateau, offshore northwestern Australia: Deep seismic reflection/refraction evidence for simple and pure shear mechanisms, Geology, 17, 15-18, 1989.

Mutter, J. C., Buck, W. R., and Zehnder, C. M.: Convective partial melting: 1. A model for the formation of thick basaltic sequences during the initiation of spreading, J. Geophys. Res.-Sol. Ea., 93, 1031-1048, 1988.

Odé, H.: Mechanical Analysis of the Dike Pattern of the Spanish Peaks Area, Colorado, Geol. Soc. Am. Bull., 68, 567-576, 1957.

Okubo, C. H. and Martel, S. J.: Pit crater formation on Kilauea volcano, Hawaii, J. Volcanol. Geoth. Res., 86, 1-18, 1998.

Paquet, F., Dauteuil, O., Hallot, E., and Moreau, F.: Tectonics and magma dynamics coupling in a dyke swarm of Iceland, J. Struct. Geol., 29, 1477-1493, 2007.

Paumard, V., Bourget, J., Payenberg, T., Ainsworth, R. B., George, A. D., Lang, S., Posamentier, H. W., and Peyrot, D.: Controls on shelf-margin architecture and sediment partitioning during a syn-rift to post-rift transition: Insights from the Barrow Group (Northern Carnarvon Basin, North West Shelf, Australia), EarthSci. Rev., 177, 643-677, 2018.

Peng, P.: Precambrian mafic dyke swarms in the North China Craton and their geological implications, Sci. China Earth Sci., 58, 649$675,2015$.

Phillips, T. B., Magee, C., Jackson, C. A.-L., and Bell, R. E.: Determining the three-dimensional geometry of a dike swarm and its impact on later rift geometry using seismic reflection data, Geology, 46, 119-122, 2018.

Plazibat, S., Rasgido, A., and Paredes, J. M.: Subsurface characterization of Cenozoic igneous activity at Cerro Dragón area (Golfo San Jorge Basin, central Patagonia): Implications for basin evolution and hydrocarbon prospectivity, J. South Am. Earth Sci., 96, 102389, https://doi.org/10.1016/j.jsames.2019.102389, 2019.

Pollard, D. D., Delaney, P. T., Duffield, W. A., Endo, E. T., and Okamura, A. T.: Surface deformation in volcanic rift zones, Tectonophysics, 94, 541-584, 1983.

Rabbel, O., Galland, O., Mair, K., Lecomte, I., Senger, K., Spacapan, J. B., and Manceda, R.: From field analogues to realistic seismic modelling: a case study of an oil-producing andesitic sill 
complex in the Neuquén Basin, Argentina, J. Geol. Soc., 175, 580-593, 2018.

Reeve, M. T., Jackson, C. A. L., Bell, R. E., Magee, C., and Bastow, I. D.: The stratigraphic record of prebreakup geodynamics: Evidence from the Barrow Delta, offshore Northwest Australia, Tectonics, 35, 1935-1968, 2016.

Rey, S. S., Planke, S., Symonds, P. A., and Faleide, J. I.: Seismic volcanostratigraphy of the Gascoyne margin, Western Australia, J. Volcanol. Geoth. Res., 172, 112-131, 2008.

Rivalta, E., Taisne, B., Bunger, A., and Katz, R.: A review of mechanical models of dike propagation: Schools of thought, results and future directions, Tectonophysics, 638, 1-42, 2015.

Robb, M. S., Taylor, B., and Goodliffe, A. M.: Re-examination of the magnetic lineations of the Gascoyne and Cuvier Abyssal Plains, off NW Australia, Geophys. J. Int., 163, 42-55, 2005.

Rohrman, M.: Intrusive large igneous provinces below sedimentary basins: An example from the Exmouth Plateau (NW Australia), J. Geophys. Res.-Sol. Ea., 118, 4477-4487, 2013.

Rohrman, M.: Delineating the Exmouth mantle plume (NW Australia) from denudation and magmatic addition estimates, Lithosphere, 7, 589-600, 2015.

Rubin, A. M.: Dike-induced faulting and graben subsidence in volcanic rift zones, J. Geophys. Res.-Sol. Ea., 97, 1839-1858, 1992.

Rubin, A. M. and Pollard, D. D.: Dike-induced faulting in rift zones of Iceland and Afar, Geology, 16, 413-417, 1988.

Schultz, R. A.: Fault-population statistics at the Valles Marineris Extensional Province, Mars: implications for segment linkage, crustal strains, and its geodynamical development, Tectonophysics, 316, 169-193, 2000.

Schweig III, E. S., Shen, F., Kanter, L. R., Luzietti, E. A., VanArsdale, R. B., Shedlock, K. M., and King, K. W.: Shallow seismic reflection survey of the Bootheel lineament area, southeastern Missouri, Seismol. Res. Lett., 63, 285-295, 1992.

Sigmundsson, F., Hooper, A., Hreinsdóttir, S., Vogfjörd, K. S., Ófeigsson, B. G., Heimisson, E. R., Dumont, S., Parks, M., Spaans, K., and Gudmundsson, G. B.: Segmented lateral dyke growth in a rifting event at Bárðarbunga volcanic system, Iceland, Nature, 517, 191-195, 2015.

Speight, J., Skelhorn, R., Sloan, T., and Knaap, R.: The dyke swarms of Scotland, Igneous rocks of the British Isles, 449-459, 1982.

Stagg, H. and Colwell, J.: The structural foundations of the Northern Carnarvon Basin, The sedimentary basins of Western Australia: Proceedings of Petroleum Exploration Society of Australia Symposium, Perth, 1994, 349-365, 1994.

Stagg, H., Alcock, M., Bernardel, G., Moore, A., Symonds, P., and Exon, N.: Geological framework of the outer Exmouth Plateau and adjacent ocean basins, Geosci. Austr., 13, 169 pp., 2004.

Symonds, P. A., Planke, S., Frey, O., and Skogseid, J.: Volcanic evolution of the Western Australian Continental Margin and its implications for basin development, The Sedimentary Basins of Western Australia 2: Proc. of Petroleum Society Australia Symposium, Perth, WA, 1998.

Thomson, K.: Determining magma flow in sills, dykes and laccoliths and their implications for sill emplacement mechanisms, Bull. Volcanol., 70, 183-201, 2007.

Tindale, K., Newell, N., Keall, J., and Smith, N.: Structural evolution and charge history of the Exmouth Sub-basin, northern Carnarvon Basin, Western Australia, The Sedimentary Basins of
Western Australia 2: Proc. of Petroleum Society Australia Symposium, Perth, WA, 1998, 473-490, 1998.

Townsend, M. R., Pollard, D. D., and Smith, R. P.: Mechanical models for dikes: a third school of thought, Tectonophysics, 703, 98118, 2017.

Trippanera, D., Acocella, V., Ruch, J., and Abebe, B.: Fault and graben growth along active magmatic divergent plate boundaries in Iceland and Ethiopia, Tectonics, 34, 2318-2348, 2015a.

Trippanera, D., Ruch, J., Acocella, V., and Rivalta, E.: Experiments of dike-induced deformation: Insights on the long-term evolution of divergent plate boundaries, J. Geophys. Res.-Sol. Ea., 120, 6913-6942, 2015b.

Underhill, J. R. and Partington, M. A.: Jurassic thermal doming and deflation in the North Sea: implications of the sequence stratigraphic evidence, in: Geological Society, London, Petroleum Geology Conference series, Geol. Soc. Lond., 4, 337-345, 1993.

Velayatham, T., Holford, S. P., and Bunch, M. A.: Ancient fluid flow recorded by remarkably long, buried pockmark trains observed in 3D seismic data, Exmouth Plateau, Northern Carnarvon basin, Mar. Petrol. Geol., 95, 303-313, 2018.

Velayatham, T., Holford, S., Bunch, M., King, R., and Magee, C.: 3D Seismic Analysis of Ancient Subsurface Fluid Flow in the Exmouth Plateau, Offshore Western Australia, in: The Sedimentary Basins of Western Australia V: Proceedings of the Petroleum Exploration Society of Australia Symposium, West Australian Basins Symposium, Perth, Western Australia, 24, 2019.

Walker, G. P.: Koolau Dike Complex, Oahu: Intensity and origin of a sheeted-dike complex high in a Hawaiian volcanic edifice, Geology, 14, 310-313, 1986.

Wall, M., Cartwright, J., Davies, R., and McGrandle, A.: 3D seismic imaging of a Tertiary Dyke Swarm in the Southern North Sea, UK, Basin Res., 22, 181-194, 2010.

Willcox, J. and Exon, N. J.: The regional geology of the Exmouth Plateau, APPEA J., 16, 1-11, 1976.

Wilson, L. and Head, J. W.: Tharsis-radial graben systems as the surface manifestation of plume-related dike intrusion complexes: Models and implications, J. Geophys. Res.-Planet., 107, E85057, https://doi.org/10.1029/2001JE001593, 2002.

Woods, J., Winder, T., White, R. S., and Brandsdóttir, B.: Evolution of a lateral dike intrusion revealed by relatively-relocated dikeinduced earthquakes: The 2014-15 Bárðarbunga-Holuhraun rifting event, Iceland, Earth Planet. Sc. Lett., 506, 53-63, 2019.

Wright, T., Ebinger, C., Biggs, J., Ayele, A., Yirgu, G., Keir, D., and Stork, A.: Dyke-maintained rift segmentation at continental rupture - the 2005 Dabbahu (Afar) rifting episode, Nature, 442, 291-294, 2006.

Wyrick, D., Ferrill, D. A., Morris, A. P., Colton, S. L., and Sims, D. W.: Distribution, morphology, and origins of Martian pit crater chains, J. Geophys. Res., 109, E06005, https://doi.org/10.1029/2004JE002240, 2004.

Wyrick, D. Y. and Smart, K. J.: Dike-induced deformation and Martian graben systems, J. Volcanol. Geoth. Res., 185, 1-11, 2009. 